2018

\title{
Banking in the Digital Age - Who Is Afraid of Payment Disintermediation?
}

Benjamin Geva

Osgoode Hall Law School of York University, bgeva@osgoode.yorku.ca

Follow this and additional works at: http://digitalcommons.osgoode.yorku.ca/all_papers

Part of the Banking and Finance Law Commons

\section{Repository Citation}

Geva, Benjamin, "Banking in the Digital Age - Who Is Afraid of Payment Disintermediation?" (2018). All Papers. 322.

http://digitalcommons.osgoode.yorku.ca/all_papers/322

This Working Paper is brought to you for free and open access by the Research Papers, Working Papers, Conference Papers at Osgoode Digital

Commons. It has been accepted for inclusion in All Papers by an authorized administrator of Osgoode Digital Commons. 


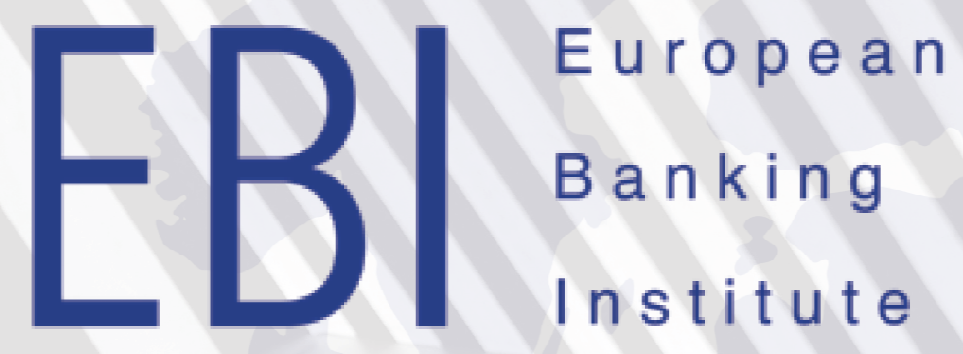

EBI Working Paper Series

2018 - no. 23

Benjamin Geva

Banking in the Digital Age - Who is Afraid of Payment Disintermediation? 
The European Banking Institute based in Frankfurt is an international centre for banking studies resulting from the joint venture of Europe's preeminent academic institutions which have decided to share and coordinate their commitments and structure their research activities in order to provide the highest quality legal, economic and accounting studies in the field of banking regulation, banking supervision and banking resolution in Europe. The European Banking Institute is structured to promote the dialogue between scholars, regulators, supervisors, industry representatives and advisors in relation to issues concerning the regulation and supervision of financial institutions and financial markets from a legal, economic and any other related viewpoint. The Academic Members of EBI are the following:

1. Universiteit van Amsterdam, Amsterdam, The Netherlands

2. Universiteit Antwerpen, Antwerp, Belgium

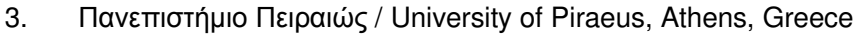

4. Alma Mater Studiorum - Università di Bologna, Bologna, Italy

5. Academia de Studii Economice din București (ASE), Bucharest, Romania

6. Universität Bonn, Bonn, Germany

7. Trinity College, Dublin, Ireland

8. Goethe-Universität, Frankfurt, Germany

9. Universiteit Gent, Ghent, Belgium

10. Helsingin yliopisto (University of Helsinki, Helsinki, Finland)

11. Universiteit Leiden, Leiden, The Netherlands

12. Universidade Católica Portuguesa, Lisbon, Portugal

13. Universidade de Lisboa, Lisbon, Portugal

14. Univerze v Ljubljani / University of Ljubljana, Ljubljana, Slovenia

15. Queen Mary University of London, London, United Kingdom

16. Université du Luxembourg, Luxembourg

17. Universidad Autónoma Madrid, Madrid, Spain

18. Universidad Complutense de Madrid/CUNEF, Madrid, Spain

19. Johannes Gutenberg University Mainz (JGU), Mainz, Germany

20. University of Malta, Malta

21. Università Cattolica del Sacro Cuore, Milan, Italy

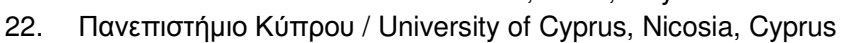

23. Radboud Universiteit, Nijmegen, The Netherlands

24. Université Panthéon - Sorbonne (Paris 1), Paris, France

25. Université Panthéon-Assas (Paris 2), Paris, France

26. Stockholms Universitet/University of Stockholm, Stockholm, Sweden

27. Tartu Ülikool / University of Tartu, Tartu, Estonia

Supervisory Board of the European Banking Institute:

Thomas Gstaedtner, President of the Supervisory Board of the European Banking Institute

Enrico Leone, Chancellor of the European Banking Institute

\section{EBI Working Paper Series}

EBI Working Paper Series are a project of the European Banking Institute e.V.. EBI Working Paper Series represent a selection of academic researches into the area of banking regulation, banking supervision and banking in general which have been drafted by professors and researchers of EBI Academic Members and selected by the Editorial Board.

\section{Editorial Board}

T. Bonneau, D. Busch, G. Ferrarini, P. Mülbert, C. Hadjiemmanuil, I. Tirado, T. Tröger, and E. Wymeersch. 


\title{
BANKING IN THE DIGITAL AGE - WHO IS AFRAID OF PAYMENT DISINTERMEDIATION?
}

By

\section{Professor Benjamin GEVA*}

\author{
LL.B. Jerusalem; LL. M., SJD Harvard \\ Osgoode Hall Law School York University, Toronto, Canada \\ Counsel, Torys LLP Toronto \\ E-mail: bgeva@osgoode.yorku.ca \\ http://www.osgoode.yorku.ca/faculty-and-staff/geva-benjamin/
}

\begin{abstract}
$\underline{\text { Abstract }}$
Throughout the ages, banks have evolved as intermediaries taking deposits of funds, lending money, and providing payment services. In the process they became also suppliers of commercial bank money, now only in the form of bank deposits. Following a historical review as to how moneychangers and goldsmiths became bankers, the paper points out that money and payment digitization has brought some challenges to the traditional role of banks as intermediaries. First, the digital age is about to facilitate the availability of central bank money balances or their equivalent to the public. Second, cryptocurrencies and blockchains were born. Third, claim-check centralized digital currencies have been created. This paper argues that availability to the public of central bank money, in the form of either full-reserve banking or plain sovereign money, is unlikely to affect the role of banks other than in money creation. The paper goes on to argue that cryptocurrencies are mostly not a new form of money and that in essence blockchains do not pose a major threat to the traditional interbank settlement system; at most they spur improvements in legacy systems. Finally, the argument goes, the creation of claim-check centralized digital currencies will give banks enough space to continue their role in providing payment services and even create alternative currencies fully backed by fiat ones. Ultimately banks will retain their role as intermediaries; Fintech does not have a payment services model which will supersede banking so that, in order to competitively provide payment services, IT firms will have to become banks.
\end{abstract}

\footnotetext{
* For research assistance in the final preparation of the manuscript I am grateful to Damian Lu, of the 2019 graduating class of Osgoode Hall Law School. Any error and technology misunderstanding is exclusively of the author who acknowledges lack of computer science and engineering background.
} 


\section{Contents}

\section{Introduction}

II. Deposit banking, payment services, and paper money: Historical perspective on payments intermediation
(i) Antiquity
(ii) Middle Ages
(iii) Post-Medieval Era

III. The coming of the cyber age: Electronic payments, e-money, access to central bank balances, the blockchain, and digital currencies

(i) The advent of electronic banking and e-money

(ii) Availability of central bank account balances and their equivalents to the public

(iii) Cryptocurrencies and blockchains

(iv) Claim-check centralized digital currencies

\section{Conclusion}

\section{8@Copyright}

by

Benjamin Geva

All Rights Reserved 


\section{$\underline{\text { I. Introduction }}$}

The essence of commercial banking has been the taking of deposits (or other repayable funds) from the public and lending. ${ }^{1}$ Linked to these functions is the provision of payment services.

Accordingly,

To be recognized as a bank ... an institution is expected [i] to receive deposits of money from its customers; [ii] to maintain current accounts for them; [iii] to provide advances in the forms of loans or overdrafts; and [iv] to manage payments on behalf of its customers by collecting and paying cheques, bills, and other forms of 'bank currency'2

Historically, commercial banking (banking) emerged as a form of financial intermediation between savers (depositors) and borrowers. The banker (or bank) ${ }^{3}$ took from the public deposits either in specie or in commodity money; what was deposited was both owed by the banker to the depositors and at least in part available to be lent by the banker to borrowers. Loans were mostly credited into borrowers' deposit accounts with the lending bankers in part to be used by borrowers to make payments. In this environment, payment intermediation in the form of non-cash payment services evolved as an outgrowth of deposit taking or, more in general, of maintaining deposit accounts for customers, whether the original depositors, or the borrowers who deposited the proceeds of the loan. ${ }^{4}$ This business model has been workable as long as not all depositors required payment in specie from the banker at the same time. In normal circumstances, it sufficed for a banker to keep at hand enough specie or cash to satisfy reasonable demand. Monitoring depositors' payment activity in accounts facilitated credit decision-making and led to specialization in advancing information-intensive non-traded loans,

\footnotetext{
${ }^{1}$ See e.g. definition of 'credit institution' in Article 4(1)(1) of Regulation (EU) No 575/2013 of the European Parliament and of the Council of 26 June 2013 on prudential requirements for credit institutions and investment firms and amending Regulation (EU) No 648/2012, online: http://eur-lex.europa.eu/legalcontent/EN/TXT/?uri=celex:32013R0575, accessed December 22, 2017.
}

${ }^{2}$ Edwin Green, Banking: An Illustrated History (New York: Rizoli, 1989) at 11. For a similar judicial discussion on the characteristics of banking see Lord Denning MR judgement in United Dominion Trust v. Kirkwood [1966] 2 QB $31(\mathrm{CA})$ at $445-447$.

\footnotetext{
${ }^{3}$ Grammatically, 'banker' is the professional individual, while 'bank' is the institution. Until incorporation, there was no real difference and this paper will use to the two terms interchangeably. Note also that 'commercial banking', 'banking', and 'deposit banking' are, generally speaking, synonyms, and unless indicated otherwise are used in this paper interchangeably.

${ }^{4}$ See e.g. Meir Kohn, "Early Deposit Banking” (February 1999) Department of Economics Darmouth College, Working Paper 99-03, online: <http://sites.dartmouth.edu/mkohn/files/2017/03/99-03.pdf>, accessed 9 January 2018; and James McAndrews and William Roberds, "Payment Intermediation and the Origins of Banking" (August 1999) Federal Reserve Bank of Atlanta, Working Paper 99-11, online: <https://www.frbatlanta.org/research/publications/wp/1999/11.aspx>, accessed 9 January 2018. Both studies cover the Middle Ages and overlook Antiquity.
} 
which became a principal niche for a profitable commercial banking business as well as effective financial intermediation for the economy as a whole.

Already way back in Antiquity ${ }^{5}$ the evolution of mechanisms for payments initiated by the issue of payment orders had been part and parcel of the emergence of 'banking' as a form of financial intermediation between depositors to, and borrowers from, the depositary. ${ }^{6}$

Furthermore, over centuries the architecture of the banking system evolved to satisfy the need to carry out noncash payment transactions between customers of separate banks by the creation of interbank networks. For its part, lending out of deposits meant a fractional reserve system which necessitated the establishment of liquidity facilities to ensure the smooth flow of payments. Finally, for their part, banknotes, of which at present mainly consists cash, originated as circulating receipts for deposited funds.

In the modern economy, payments are predominantly made by means of transfers through bank accounts, and otherwise the delivery of banknotes. As conduits of funds transfers, banks operate as intermediaries between payers and payees. They also distribute to their customers banknotes issued by the central bank. The recent emergence of digital currencies, facilitating payments outside the banking system, as well as in items not created throughout banking operations, has put to test these fundamentals and particularly challenged the architectural premises of the present banking system. This paper is designed to examine these challenges as well as the resilience of the banking system to meet them. Drawing on my previous work, ${ }^{7}$ Part II presents the evolution of deposit banking architecture throughout the ages facilitating both the intermediation of noncash payments through the banking system and the emergence of banknotes. Proceeding from another part of my earlier work, ${ }^{8}$ Part III addresses the impact of the cyber ${ }^{9}$ revolution in payments first in improving on the earlier paper-based system and then in challenging altogether its underlying architecture as well as the role of banks and bank products in providing payment services. The discussion examines the possible response by banks, their continued functions in a new era, as well as their adaptation to new demands, needs, and requirements. The particular challenges to be examined are in the broader context of

\footnotetext{
${ }^{5}$ Roughly speaking, Antiquity comes to an end with the beginning of the Middle Ages, usually marked by the fall of Rome in 476 CE.

${ }^{6}$ For an insight into the process, though well into the later Medieval period, see e.g. Abbot Payson Usher, The Early History of Deposit Banking in Mediterranean Europe vol 1 (Cambridge, Mass: Harvard University Press, 1943) particularly at 3-25.

${ }^{7}$ Particularly Chapters 3, 8, and 10 of Benjamin Geva, The Payment Order of Antiquity and the Middle Ages: A Legal History (Oxford and Portland, Oregon: Hart Publishing, 2011).

${ }^{8}$ In particular see Benjamin Geva, The Law of Electronic Funds Transfers (New York: Matthew Bender, Looseleaf updated to 2017) § 1.04[7] (of which an earlier version is the basis of Benjamin Geva, "Disintermediating Electronic Payments: Digital Cash and Virtual Currencies" (2016) 31: 12 J Intl Banking L \& Reg); as well as Gene Neyer and Benjamin Geva, "Blockchain and Payment Systems-What are the Benefit and Costs" (2017) 11:3 Journal of Payments Strategy \& System at 215.

9 'Cyber' is used in this article to encompass both 'electronic' and 'digital'.
} 
possible payment disintermediation. They are first, the availability of central bank money balances or their equivalent to the public; second, cryptocurrencies and blockchains; and third, claim-check centralized digital currencies. In connection with each challenge the paper will assess the risks and the potential for adaptation for a new function where necessary under a new legal relationship.

I should stress that this paper does not argue that banks could or should stay complacent in the face of a quickening pace of technological upheaval. Rather, the argument is that 'banking' embodies a model in which payment services are attached to deposit taking. As an activity undertaken in domestic as well as international networks, having evolved throughout history, banking has good odds of survival in the digital era. For sure, there are and will be new players, new methods as well as means of payment, and new regulations. Certainly, new regulatory schemes ought to cover new entrants as well as new products. But the relative advantage of providing 'storage' of, or at least access to, monetary value, side by side with institutional network linkages, are invaluable assets that are likely to continue to give an edge to banks. True, in an environment where everything moves quickly, it may even be necessary for banks to run faster in order to stay in same place. However, in the final analysis, this is what they have already done throughout the ages, and are bound to keep doing, in fulfilling their important financial and payment intermediation functions.

\section{Deposit banking, payment services, and paper money: Historical perspective on payments intermediation}

The modern payment system has been described to consist of "a complex set of arrangements involving such diverse institutions as currency, the banking system, clearing houses, the central bank, and government deposit insurance." 10 The latter element is helpful but not universally present; and yet all are components of what can be broadly described as a commercial (deposit) banking system.

Notwithstanding the substantial enhancement in complexity and importance of banking in the modern economy, its fundamentals are not at all novel. ${ }^{11}$ What follows is an abbreviated account of the evolution of payment intermediation, and to a lesser extent that of paper money in the form of cash, as an outgrowth of deposit banking.

\footnotetext{
${ }^{10}$ MS Goodfriend, "Money, Credit, Banking, and Payment System Policy", in David B Humphrey, The US Payment System: Efficiency, Risk and the Role of the Federal Reserve (Boston: Kluwer Academic Publishers, 1990) at 247.

${ }^{11}$ But cf. William Linn Westermann, "Warehousing and Trapezite Banking in Antiquity" (1951) 3 Journal of Economic and Business History 30 at 31 who highlights "a sound contrast between the relatively simple services rendered by the bank and the banker in antiquity ... and the commanding position and complex character of banking as a function of credit in the economic system of today." No doubt, such a contrast really exists, and yet it is not on point in tracing the roots of the modern bank to its predecessor in Ancient Greece.
} 
Ancient Mesopotamia has been identified as the cradle of banking operations. ${ }^{12}$ It earned this title due to the emergence of institutions providing all core banking activities, namely, deposit taking, lending ${ }^{13}$ and payment services even prior to the emergence of 'monetized' coins. ${ }^{14}$ However, this was a secondary activity for such institutions; moreover, credit was made available by depositaries out of their own capital ${ }^{15}$ and without dipping into deposits. ${ }^{16}$ As well, each customer's deposit may have been physically segregated. ${ }^{17}$ Finally, there appears to be neither evidence for the execution of non-cash payments from one account to another nor any trace of inter-institutional clearing and settlement.

In turn, the emergence of the bank as a distinct type of institution took place in Ancient Greece..$^{18}$ More specifically, the process took place in the Mediterranean territory on which

\footnotetext{
${ }^{12}$ Raymond Bogaert, Les Origines antiques de la banque de dépôt (Leyde: A. W. Sijthoff, 1966) at 129 [Bogaert, Les Origines]. Roughly speaking, at 41-129, Bogaert surveys a period extending over 1500 years commencing at the end of the $21^{\text {st }}$ century BC and covering the Ur III Empire (2112-2004 BCE), the Old Babylonian Period (20001600 BCE) which included the reign of Hammurabi (1792-1750 BCE), the Middle Assyrian and Middle Babylonian Periods (1200-750 BCE), and the Neo-Assyrian and Neo-Babylonian Kingdoms (745-539 BCE). Elsewhere in the book, at 43, Bogaert specifically discounts the existence of any comparable role to Pharaonic Egypt, the other Ancient Near Eastern civilization.
}

${ }^{13}$ A complex system of lending is traced back in Mesopotamia to the first half of the $2^{\text {nd }}$ millennium BCE. See in general, Katrien De Graefe, "Giving a Loan is Like Making Love..." in Koenraad Verboven, Katelijn Vandorpe \& Véronique Chankowski, eds, Pistoi Dia Tèn Technèn-Bankers, Loans and Archives in the Ancient World: Studies in Honour of Raymond Bogaert (Leuven: Peeters, 2008) at 3 [Verboven et al., Ancient World].

14 The earliest coins were struck in Lydia (a city-state in Asia Minor) around 700 BCE. This is the conclusion, confirming the conventional wisdom on the matter, of the thorough study by D. Kagan, "The Dates of the Earliest Coins" (1982) 86:3 Journal of Archeology 343.

\footnotetext{
${ }^{15}$ Bogaert, Les Origines, supra note 12 at 174.
}

${ }^{16}$ The gradual erosion during the first millennium BCE, culminating approximately at the first part of its second half, is noted by Francis Joannès, "Les activités bancaires en Babylonie" in Verboven et al., Ancient World, supra note 13 at 17, 19. The claim set out in Alexander Lipton and Alex "Sandy" Pentland, "Breaking the Banks: New Financial Networks Could stop the Concentration of Wealth and Increase Participation in the Economy -But only If Handled with Care" (January 2018) 318:1 Scientific American 26 who identify the origins of fractional lending out of deposits "more than 5,000 years ago in the Mesopotamian city of Ur" is supported by neither Joannès, ibid nor Bogaert, Les Origines, supra note 12 to whose expertise I prefer to defer.

${ }^{17}$ Bogaert, Les Origines, note 12 at 59, 84 n.236, 99 and nn. 311-313 \& text, supra.

${ }^{18}$ The ensuing discussion draws on Raymond Bogaert, Banques et banquiers dans les cités grecques (Leyde: A.W. Sijthoff, 1968) at 50-60 and 331-345 [Bogaert, Banques et banquiers]; Bogaert, Les Origines, supra note 12 at 130158; Edward E Cohen, Athenian Economy and Society: A Banking Perspective (Princeton NJ: Princeton University Press, 1992) at 8-11, 14-18, 62-66 and 111-121. 
Ancient Greek civilization expanded, ${ }^{19}$ almost throughout the entire classical period of that civilization. ${ }^{20}$

Thus, in the course of the $6^{\text {th }}$ century BCE, shortly after the appearance of coined money as a medium of exchange in commercial transactions, ${ }^{21}$ money changing surfaced as a profession. Shortly thereafter, the moneychanger came to accept deposits of coined money, mix them, ${ }^{22}$ lend out of them, so as to gradually become a banker. A banker effectively kept a running account for each customer, posting to it each deposit and withdrawal. ${ }^{23} \mathrm{~A}$ withdrawal from a customer's account could be made for the entire or part of a balance due on deposited money, either by the depositor himself, or by a designated payee (or on his behalf) in pursuance to the depositor's instruction.

For each payment to a designated payee, having received the payment order and being in possession of cover, the payer's banker sent a note to the payee. Having made an appropriate entry on his books in the payee's favour, the banker became accountable to the payee, regardless of whether the payee kept an account with that banker. A payee who did not have an account of the payer's bank could demand payment in cash, or where the advice note issued by the banker was made out to the payee 'or order', the payee could appoint an agent, usually another banker, to come to the payer's banker and claim on the payee's behalf payment in cash over the counter. Alternatively, the payee's banker may have been prepared to credit the payee's account in advance, on the basis of the advice note issued to the payee by the payer's banker and presented to the payee's banker by the payee, and in anticipation of subsequent payment by the payer's banker. Payment by payer's banker to the payee's banker could be effectuated either in coins, or

\footnotetext{
${ }^{19}$ Roughly speaking this territory covers Mainland Greece, Greek Islands (together roughly coinciding with the area of modern-day Greece), and the western coast of Asia Minor or Anatolia (the latter of which is part of modern-day Turkey).

${ }^{20}$ The Classical Period is said to have lasted between 500 and 336 BCE. It was preceded by the Archaic Period (stretching from 750 to $500 \mathrm{BCE}$ ) and followed by the Hellenistic Period (taking place between 336 and 146 BCE). The latter commences with Alexander the Great (336 to 323 BCE) under whose reign Greek civilization extended eastwards where it met and mingled with Eastern civilization. For time periods in the history of Ancient Greece you may visit <http://en.wikipedia.org/wiki/Timeline_of_ancient_Greece>, accessed 27 December 2017.

${ }^{21}$. Both the production and use of coined money were expanded towards the end of the $6^{\text {th }}$ and beginning of the $5^{\text {th }}$ century BCE. See in general, Arthur R Burns, Money and Monetary Policy in Early Times (New York: A.M. Kelley, 1965 , reprint of 1927) at 43-45.

${ }^{22}$ On the theory that the depositary thus became indebted for the amount of the deposit rather than to return it in specie, Bogaert, Banques et banquiers supra note 18 at 333 treats such a deposit as 'irregular' in the sense subsequently given to it by the Romans. In the view of Cohen, supra note 18 at 112-113 this is however an anachronism.

${ }^{23}$ On the evolution of accounting in Greece see e.g. Léopold Migeotte, "La compatabilité publique dans les cités Grecques: l'exemple de Délos" in Verboven et al., Ancient World, supra note 13 at 59, and Véronique Chankowski, "Banquiers, caissiers, comptables. À propos des méthodes financières dans les comptes de Délos" in Verboven et al., Ancient World, supra note 13 at 77.
} 
as part of either bilateral or multilateral setoff; and yet, neither an intercity nor an intra-city interbank clearing system, whether bilateral or multilateral, existed in Ancient Greece. ${ }^{24}$

Compared to Ancient Greece, the institutional scene in Ancient Rome $\boldsymbol{~}^{25}$ was more complex ${ }^{26}$ and yet, this complexity did not lead to an overall advancement in banking practices. Nonetheless, in three major respects Roman banking practice went beyond that of the Greek. First, the receiver-banker could be treated as the first money transmitter, to whom funds are delivered with the view of making a specific payment. However, money transmission by a receiver-banker may have developed under narrow circumstances, in the context of private auctions, ${ }^{27}$ and in any event did not extend to cover payment between geographically distant parties. Second, as in Ancient Greece, there was in Ancient Rome neither an intra-city nor intercity multilateral interbank clearing and settlement system. ${ }^{28}$ However, nascent interbank correspondent arrangements, under which one bank held funds in an account with the other, developed, particularly in the same city, ${ }^{29}$ but also in different cities so as to facilitate payments

\footnotetext{
${ }^{24}$ Bogaert, Banques et banquiers supra note 18 at 344-345 and 413.

${ }^{25}$ Between around $500 \mathrm{BCE}$ and $30 \mathrm{CE}$ the Roman Republic grew from a city state to dominate first Italy, then the Western Mediterranean and, finally, the entire Mediterranean basin. In the process, Rome had undergone a fundamental change in its system of government and came to be the Roman Empire. The City of Rome ultimately fell at $476 \mathrm{CE}$, an event which marks the end of the Roman period in the West. An outline of Roman history can be found, for example, at <http://www.forumromanum.org/history/>, accessed 28 December 2017. In 320 CE Emperor Constantine chose Byzantium (present-day Istanbul) as the new capital of the Empire and renamed it Constantinopolis. He officially divided the Empire into an Eastern and Western Empires in 395 CE. The Eastern Empire survived for close to 1,000 years after the fall of Rome, until Constantinopolis fell to the hands of the Ottoman Turks in $1453 \mathrm{CE}$, except that particularly as of the rise of Islam at the $7^{\text {th }}$ century CE it had been considerably weakened long before its ultimate fall.
}

${ }^{26}$ For this institutional framework see e.g. Jean Andreau, Banking and Business in the Roman World (Cambridge: Cambridge University Press, 1999) at 30-49 [translated by Janet Lloyd] [Andreau, Banking] at 30-49; as well as Koenraad Verboven, "Faeneratores, Negotiatores, and Financial Intermediation in the Roman World (Late Republic and Early Empire)" in Verboven et al., Ancient World, supra note 13 at 211 [Verboven, "Faeneratores"]; and Koenraad Verboven, "The Sulpicii from Puteoli, argentarii or faeneratores?" in Pol Defosse, ed, Hommages à Carl Deroux; III-Histoire et épigraphie, Droit (Bruxelles: Éditions Latomus, 2003) at 429. See also Peter Temin, "Financial Intermediation in the Early Roman Empire" (2004) 64.3 Journal of Economic History 705.

${ }^{27}$ See in general, Hubert Cancik and Helmuth Schneider, eds, Brill's New Pauly Encyclopedia of the Ancient World: Antiquity, vol 2 (Leiden-Boston: Brill, 2003) at 331 (v. "Auctiones”). See also G. Humbert, “Auctio", in Charles Victor Daremberg and Edmond Saglio, eds, Dictionnaire Des Antiquités Greques et Romaines vol 1, Part 1 (Graz: Akademische Durck- u. Verlagsanstalt, 1969) at 543. For the controversy as to the role the banker played in a public auction see e.g. Fritz Sturm, "Stipulation argentaria" in Felix Bernard Joseph Wubbe \& Johan Albert Ankum, Mélanges Felix Wubbe: offerts par ses collègues et ses amis à l'ocassion de son soixante-dixiéme anniversaire (Fribourg: Éditions universitaire, 1993) at 453, 460-63; Hans Ankum, "Quelques problèmes concernant les ventes aux enchères en droit romain classique”, Studi in onore di Gaetano Scherillo, vol 1, 377 (Milan: Cisalpino-La goliardica, 1972); and JAC Thomas, "The Auction in Roman Law” (1957) Juridical Review 42.

${ }^{28}$ Notwithstanding Sam Maxwell, De la délégation en droit romain (Bordeaux: Imprimerie $V^{\mathrm{e}}$ Cadoret, 1895) at 111.

${ }^{29}$ See Andreau, Banking, supra note 26 at 43, who specifically claims that in the Roman world "[t]here was no system of institutionalized compensation between banks of the same city." 
between geographically distant parties. ${ }^{30}$ A non-cash payment could have been carried out between accounts of two depositors, either in the same bank, or in two banks situated in the same small town or within a specific market, whether permanent or periodic.

Third, deposit bankers operated under strict bookkeeping requirements, and were obligated to record their monetary operations in account books called rationes. An account book (ratio in singular) was also known as a ratio accepti et expensi ('an account of deposits and payments') and ratio implicita proper accepta et data ('a complex account including both deposits and payments'). A deposit banker was required to make such books available for production in a trial involving a client, even where the deposit banker was not a party to the litigation. ${ }^{31}$ For his part, the deposit banker was obligated to maintain books, to account for the various entries, and to state a balance owed between himself and the customer. ${ }^{32}$

Payment services were operated in conjunction with deposit banking in Greco-Roman Egypt. ${ }^{33}$ To begin with, public granaries in Greco-Roman Egypt, connected into a network of grain depositaries, operated a countrywide system of payment in agricultural products, such as oil and wine. Particularly however, they ran grain warehouse banking, facilitating payments out of and into deposits of grain, for both public authorities and individuals. ${ }^{34}$ The system maintained grain accounts and recorded transfers. For each yearly harvest of each type of grain the various deposits were physically amalgamated so that credit to an account reflected a claim to a share in

\footnotetext{
${ }^{30}$ See Jean G Platon, Les Banquiers dans la législation de Justinien (Premiére partie) (Paris: Librairie Recuil Sirey, 1912) at 108-09.

${ }^{31}$ See Adolf Berger, Encyclopedic Dictionary of Roman Law (Philadelphia: American Philosophical Society, 1953) at 366-367 (v. "Argentarii").

${ }^{32}$ Edmond Guillard, Les Banquiers Athéniens et Romains suivis du Pacte de Constitut en Droit Romain (Paris, Lyon: Guillaumin, H. Georg, 1875) at 52 sets out these obligations and discusses them at length in 52-79.

${ }^{33}$ Following the death of Alexander the Great in 323 BCE, and after the ensuing partition of his empire, Egypt fell into Ptolemy's hands. His successors, the Ptolemies, ruled Egypt until 30 BCE when the country was conquered by the Romans. With the partition of the Roman Empire in the course of the $4^{\text {th }}$ century CE, the Byzantines succeeded the Romans; they stayed in power until $642 \mathrm{CE}$, when the Arabs took over and the Islamic epoch commenced. For Egypt, the entire era of close to a millennium, between Alexander the Great and the introduction of Islam, is loosely referred to as Greco-Roman. This historical sketch draws on <http://www.sis.gov.eg/section/0/701?lang=en-us>, accessed 27 December 2017, and <http://en.wikipedia.org/wiki/Alexander_the_Great $\geq$, accessed 27 December 2017. See also <http://en.wikipedia.org/wiki/Roman_Empire $\geq$, accessed 27 December 2017, and <http://en.wikipedia.org/wiki/Muslim_conquests>, accessed 27 December 2017.

${ }^{34}$ The system is concisely described by Claire Préaux, L'Économie royale des Lagides (Bruxelles: Édition de la Fondation Égyptogique, 1939) at 142, as well as by Michael Rostovtzeff, The Social and Economic History of the Hellenistic World, vol 2 (Oxford: Clarendon Press, 1941) at 1287. See also Gyles Davies, A History of Money: from Ancient Times to Present Day, 3rd ed (Cardiff: University of Wales Press, 2002) at 52-55 and Westermann, supra note 11 at 32-33. The authoritative text relied by all is in German: Friedrich Preisigke, Girowesen im griechischen Ägypten (Strassburg: Verlad von Schlesier \& Schweikhardt, 1910) [Reprinted: Hildesheim, New York: Georg Olms Verlag, 1971], discussing the grain giro system at 62-184, particularly at 89-92, 101-102, and 128-130 (see also relevant translated documents reproduced at 147-173), in connection with which I had the benefit of a partial unofficial translation.
} 
the mixture rather than to a physically segregated or separate deposit; it seems though, that no lending was made out of the mixture, so that full reserve was held to back all credits to the deposit accounts. ${ }^{35}$

Book-based transfers could occur between accounts in the same granary, same region, or different regions. For an inter-granary transfer, an adjustment was made not only to transferor's and transferee's accounts, but also over a system of inter-granary accounts. ${ }^{36}$ A comprehensive account management system thus existed in each granary, in each region, as well as in Alexandria, from which the entire system was overseen. Effectively, this was the forerunner for a nationwide credit-push giro mechanism, ${ }^{37}$ under which payment orders were executed by means of crediting and debiting accounts. ${ }^{38}$ The system was however doomed to wither away together with the disappearance of specie and kind as universal mediums of exchange. ${ }^{39}$

So far as the monetary economy of Greco-Roman Egypt ${ }^{40}$ was concerned, the banking system formed a network and assumed a key role in carrying out treasury operations for the

\footnotetext{
${ }^{35}$ For this understanding of the system (on the basis of Westermann's article, supra note 11) see Jeffery Williams, "Fractional Reserve Banking in Grain" (1984) 16 Journal of Money, Credit and Banking 488 at 488 n. 1.

${ }^{36}$ For example, a transfer from a Depositor A in Granary A to a depositor B in Granary B, resulted not only in an adjustment of Depositors' accounts, but also in an adjustment that reflected the claim of Granary B on Granary A where the grain in the amount of the transfer remained kept.

37 'Giro' (coming from Greek 'gigros', and meaning ring, circular or cyclical) usually narrowly denotes a 'creditpush' mechanism for a non-cash payment between two accounts (as in http://en.wikipedia.org/wiki/Giro, accessed 27 December 2017). Alternatively, it may more broadly denote any bookkeeping transfer (as in Westermann, supra note 11 at 49) or transfer operations (as in Rostovtzeff, supra note 34 at 1279). In this latter (broad) sense it is any non-cash payment between two bank accounts, regardless of whether it is a 'credit-push' or 'debit-pull' mechanism.

${ }^{38}$ Possibly also, circulating credit notes attesting to credit posted to a grain account are said to have been used as payment devices. See e.g. Roger S Bagnall and Raymond Bogaert, "Orders for Payment from A Banker's Archive: Papyri in the Collection of Florida State University" (1975), in Raymond Bogaert, Trapezitica Aegyptiaca: Recueil de recherches sur la banque en Égypte Gréco-Romaine (Firenze: Edizioni Gonelli, 1994) at 240 [Trapezitica]. No mention of such credit notes appears in Preisigke, supra note 34.
}

${ }^{39}$ And yet, a temporary revival of grain banking, consisting also of lending out of amalgamated deposits, occurred in
the Chicago in the course of the $19^{\text {th }}$ century. See Williams, supra note 35 .

\footnotetext{
${ }^{40}$ Bogaert researched and wrote extensively on the subject. His work, consisting of 20 articles, mostly in French, to 1994 (originally published elsewhere) is collated in Trapezitica, supra note 38. Six subsequent articles (which are thus not part of the collection) are Raymond Bogaert, "Liste géographic des banques et des banquiers de l'Égypte romaine, 30A-284" (1995) 109 Zeitschrift-für Papyrologie und Epigraphik 133; Raymond Bogaert, "La Banque en Égypte Byzantine" (1997) 116 Zeitschrift-fur Papyrologie und Epigraphik 85; Raymond Bogaert, "Les opérations des banques de l'Égypte Ptolémaïque" (1998) 29 Ancient Society 49; Raymond Bogaert, "Liste géographique des banques et des banquiers de l'Égypte Ptolémaïque" (1998) 120 Zeitschrift-für Papyrologie und Epigraphik 165; Raymond Bogaert, "Les opérations des banques de l'Égypte romaine" (2000) 30 Ancient Society 135; and Raymond Bogaert, "Les documents bancaires de l'Égypte Gréco-Romaine et Byzantine" (2001) 31 Ancient Society 173. Bogaert commenced the first of these last six articles ("Liste geographic" (1995), ibid at 133 text at n. 1) by conceding that for health reasons he had abandoned his plan to synthesize his extensive research on banks in GrecoRoman Egypt into a monograph. Since then, he unfortunately passed away (in October 2009). A recent work
} 
central government and other public authorities. Each regional royal bank operated in conjunction with a network of village banks, which effectively functioned as branch offices for royal banks or more precisely, as points of collections and disbursements of funds ${ }^{41}$ throughout the various districts of the country. However, the Royal Treasury, or the basilicon, in Alexandria, ${ }^{42}$ did not serve as a central bank ${ }^{43}$ it neither maintained accounts for all deposits throughout the country, nor received surplus balances for such accounts, other than for the king. Nor did the basilicon oversee the operation of the entire network; it did not even maintain accounts for the various royal banks into which adjustments for inter-district transfers could be made. Rather, each royal bank kept a separate set of records for its own account holders. Effectively, together with its village bank network, a royal bank operated as a standalone independent bank. It follows that there was no infrastructure facilitating a countrywide system for inter-district non-cash payments from an account in one royal bank to an account in another.

Throughout the Ptolemaic era, ${ }^{44}$ both royal and private banks maintained deposit accounts for individuals. ${ }^{45}$ Available documentation supports the existence of funds transfers from one account to another ${ }^{46}$ in private banks ${ }^{47}$ as well as for tax payments from accounts maintained in royal banks. ${ }^{48}$ Documentation further supports the existence of bilateral correspondent relations between private banks, namely instances where one bank holds an account with another. ${ }^{49}$ At the same time, there is no indication of any multilateral bank clearing

covering the first part of the period is Sitta von Reden, Money in Ptolemaic Egypt: From the Macedonain Conquest to the End of the Third Century BC (Cambridge: Cambridge University Press, 2007) at 257-296.

\footnotetext{
${ }^{41}$ From a modern perspective, they were not 'bank branches' as, per explanation that immediately follows, they did not maintain on their books the principal accounts of their customers.

42 Bogaert's tentative statement to that effect in Bogaert, "Le statut des banques en Égypte Ptolémaïque" (1981), Trapezitica, supra note 38 at 56 as well as in Bogaert, "Recherches sur la banque en Égypte Gréco-Romaine" (1987), Trapezitica, supra note 38 at 6 is expressed more confidently in Bogaert, "Les opérations des banques de l' Égypte Ptolémaïque" supra note 40 at 117.

${ }^{43}$ Among others, this has been a contested point. The present analysis follows Bogaert, who on this issue determined against the existence of a central bank in Alexandria. For his view on the point, in conjunction with a survey of the debate, see e.g. Bogaert, "Le statut des banques en Égypte Ptolémaïque" ibid at 47.

44 The Ptolemies, ruled Egypt following the death of Alexander the Great in 323 BCE until 30 BCE when the country was conquered by the Romans. See note 33 supra.

${ }^{45}$ Bogaert, "Les opérations des banques de l'Égypte Ptolémaïque”, supra note 40, respectively at 113-116, 124-128, 135-142.

${ }^{46}$ Bogaert, ibid.

${ }^{47}$ Bogaert, ibid at 136-137.

${ }^{48}$ Bogaert, ibid at 115.

${ }^{49}$ Bogaert, ibid at 135.
} 
arrangement; and certainly, any claim to the existence in Greco-Roman Egypt of a "centralized state giro system" 50 is not well founded.

\section{(ii) Middle Ages}

In West Europe, during the early centuries of the Middle Ages,,${ }^{51}$ the economy collapsed and trade was reduced to a trickle. Monetary economy survived only in a rudimentary form ${ }^{52}$ and banks disappeared from the West after the $4^{\text {th }}$ century CE. ${ }^{53}$ Banking services reappeared in Europe in the later part of the Middle Ages to satisfy the growing demands of trade. "Genoa happens to preserve the earliest notarial minute books that have survived (from 1154 on) ... [which] are the first source that contains a fairly large number of documents showing bankers at work." ${ }^{54}$ Deposit banking, in the form of taking deposits and lending out of them in the depositary's own name was reborn in Italy and 'exported' elsewhere ${ }^{55}$ in the course of the $12^{\text {th }}$ and $13^{\text {th }}$ centuries, as part of a commercial revolution that took place as of the $11^{\text {th }}$ century or so..$^{56}$

As originally in Ancient Greece, it was the moneychanger who commenced to take deposits, mix them, and lend out of them. By 1350, in becoming bankers,${ }^{57}$ moneychangers

\footnotetext{
${ }^{50}$ Davies, supra note 34 at 92.

${ }^{51}$ The fall of Rome in 476 CE marks the end of Antiquity and the beginning of the Middle Ages. For Western Europe, the end of the Middle Ages is marked by the discovery of the New World in 1492, or perhaps slightly later, in the early $16^{\text {th }}$ century, by the division of Western Christianity in the Reformation, the rise of humanism in the Italian Renaissance, and the beginnings of European overseas expansion. These propositions are common knowledge. See in general e.g. http://simple.wikipedia.org/wiki/Middle_Ages, accessed 27 December 2017.

52 Robert S Lopez, “The Dawn of Medieval Banking”, in Center for Medieval and Renaissance Studies, University of California, Los Angeles, ed, The Dawn of Modern Banking (New Haven and London: Yale University Press, 1979) at 1, 3-5. For payments in kind assessed in monetary value and on occasion supplemented with low-value coins that took place in the Carolingian Empire ( $8^{\text {th }}$ century CE), see e.g. Alexander Murray, Reason and Society in the Middle Ages (Oxford: Clarendon Press, 1978, rep. 2002) at 31-35.

${ }^{53}$ Bogaert, Les Origines, supra note 12 at 163-165.

${ }^{54}$ Lopez, supra note 52 at 10.

55 See e.g. André-E Sayous, "Les opérations des banquiers Italiens en Italie et aux Foires de Champagne pendant le XIII siècle" (1932) 170 Revue Historique 1 [Sayous, "banquiers Italiens"]; and M. Prestwich, "Italian Merchants in Late Thirteenth and Early Fourteenth Century England" in Centre for Medieval and Renaissance Studies, University of California, Los Angeles, ed, The Dawn of Modern Banking (New Haven and London: Yale University Press, 1979) at 77.
}

${ }^{56}$ The revolution occurred in the aftermath of the feudal anarchy of the manorial economy of the Dark Ages. For a detailed discussion on this general context, see Raymond de Roover, "Chapter II: The Organization of Trade", in MM Postan, EE Rich \& E. Miller, eds, The Cambridge Economic History of Europe Volume 3: Economic Organization and Policies in the Middle Ages (London: Cambridge University Press, 1963, rep. 1979) at 42 [de Roover, "The Organization of Trade"].

${ }^{57}$ Raymond de Roover, "New Interpretations of the History of Banking", in Julius Kirshner, ed, Business, Banking, and Economic Thought in Late Medieval and Early Modern Europe: Selected Studies of Raymond de Roover 
developed a system of local payments by book transfers, with the view of eliminating " $[t]$ he great inconvenience of making all payments in specie, especially the waste of time involved in counting coin." 58 The system that developed was strictly local; no facility for inter-city book transfers is known to have existed throughout the Middle Ages.

Thus, between late $13^{\text {th }}$ and early $14^{\text {th }}$ century the moneychangers of Venice, the campsores, became bankers. ${ }^{59}$ They accepted deposits, lent out of them, and provided payment services from and to current accounts kept with them. ${ }^{60}$ Bankers held accounts with each other which possibly allowed for intra-city interbank transfers ${ }^{61}$ which may have been settled only on irregular intervals.

Each bank kept with it only a fractional reserve, namely, a limited amount of coined money, ready to satisfy an anticipated demand for cash withdrawal; it lent or invested most of the money received on deposit. Availability of payment by book transfers, recognized by early $14^{\text {th }}$ century legislation in Venice, allowed banks to reduce cash holdings even further and increase their investments and credit extensions.

However, throughout the Continent, during the $15^{\text {th }}$ century, private deposit banks declined. Repeated bank failures undermined the confidence of merchants and further triggered hostility by public authorities. ${ }^{62}$ Together with a chronic shortage of good coins, the increased risk in keeping money with a banker led to a devaluation of "bank money" compared to that of "coined money". ${ }^{63}$ Ultimately, in a process that "did not gain momentum until the last quarter of the sixteenth century," public banks gradually replaced private banks in commercial centres. ${ }^{64}$

(Chicago and London: University of Chicago Press, 1974, Phoenix Edition 1976) at 213 [de Roover, "New Interpretations"].

58 See Raymond De Roover, "What is Dry Exchange?" in Julius Kirshner, ed, Business, Banking, and Economic
Thought in Late Medieval and Early Modern Europe: Selected Studies of Raymond de Roover (Chicago and
London: University of Chicago Press, 1974, Phoenix Edition 1976) 183 at 184 [de Roover, "Dry Exchange"].

${ }^{59}$ Sir William S Holdsworth, A History of English Law, vol 8 (London: Methuen \& Co., Sweet and Maxwell, $2^{\text {nd }}$ ed: 1937, rep. 1966) at 178.

${ }^{60}$ See in detail: Reinhold Mueller, “The Role of Bank Money in Venice, 1300-1500”, in Fondazione Giorgio Cini et al., eds, Studi veneziani (NS) vol 3 (Pisa: Giardini, 1979) at 47.

${ }^{61}$ But contrary to Mueller, ibid at 74-76, Mark Manning, Eriend Nier \& Jochen Schanz, eds, The Economics of Large-value Payments and Settlement: Theory and Policy Issues for Central Banks (Oxford: Oxford University Press, 2009) at 24 find "no conclusive evidence" for interbank transfers in Medieval Venice.

${ }^{62}$ de Roover, "New Interpretations" supra note 57 at 219.

${ }^{63}$ Frederic C Lane, Venice A Maritime Republic (Baltimore: John Hopkins University Press, 1973) at 328-29 [Lane, Venice]; for the same phenomenon in Venice at a later period see ibid at 402. See also Frederic C Lane, "Venetian Bankers, 1496-1533: A Study in the Early Stages of Deposit Banking" (1937) 45 Journal of Political Economy 187 at 200-01 [Lane, "Venetian"].

${ }^{64}$ de Roover, "New Interpretations", supra note 57 at 223. For a discussion of the public bank in Venice as a successor of the private bank system that failed primarily due to excessive lending by means of simple book entries, see Charles F Dunbar, “The Bank of Venice” (1892) 6 Quarterly Journal of Economics 308; and Gino Luzzatto, 
Heralding this development, Venice gave rise to a "distinctive style" of banking, referred to as giro banking, under which the primary purpose of banks was the making of payments on behalf of customers rather than making loans. ${ }^{65}$ For its part, The Bank of Amsterdam, "established in 1609 under the guarantee of the city," ${ }^{66}$ was a leader among the post-Medieval public banks. ${ }^{67}$

During the late Middle Ages, and to accommodate intercity commerce, exchange banking evolved in Continental Europe side by side with deposit banking. ${ }^{68}$ It was practiced by large merchants who lent to exporters located in one market, who in turn sent goods for sale in another market. Repayment was made out of the proceeds of the sale, in the destination market, by the seller's correspondent to the lender's correspondent in that market. ${ }^{69}$ This practice gave rise to the bill of payment, being the predecessor of the bill of exchange. ${ }^{70}$ For their part, exchange

"Les banques publiques de Venise (Siècles XVI-XVIII)" in Johannes Gerard van Dillen, ed, History of the Principal Public Banks (London: Frank Cass, 1964, being $2^{\text {nd }}$ impression of the $19341^{\text {st }}$ edition, The Hague: Martinus Nijhoff, 1934) at 39.

${ }^{65}$ Lane, Venice supra note 63 at 147. See also Lane, "Venetian" supra note 63 at 187 specifically rejecting earlier such institutions and stating that "Giro banks did not come into existence until the late sixteenth century, at Venice in $1584 \ldots$,

${ }^{66}$ Adam Smith, The Wealth of Nations (Chicago: University of Chicago Press, 1976; being the 1776 original text, edited by E. Cannan and prefaced by GJ Stigler, 'Two Volumes in One') vol 1 at 504.

${ }^{67}$ See e.g. Johannes Gerard van Dillen, "The Bank of Amsterdam”, in van Dillen, ed, supra note 64 at 79; Adam Smith, ibid at 503-13; Pit Dehing \& Marjolein C. 't Hart, "Linking the Fortunes: Currency and Banking, 1550-1800" in Marjolein 'T Hart, Joost Jonker \& Jan Luiten van Zanden, eds, A Financial History of the Netherlands (Cambridge: Cambridge University Press, 1997) at 45-51; and Stephen Quinn \& William Roberds, "The Big Problem of Large Bills: The Bank of Amsterdam and the Origins of Central Banking" (2007) [For a former version, see Federal Reserve Bank of Atlanta, Working Papers Series, Working Paper 2005-16, August 2005 (albeit the latter contains lots of econometrics which is inaccessible to a non-specialist such as myself)]. For money and banking in Amsterdam see also Jan De Vries \& An van der Woulde, The First Modern Economy: Success, Failure, and Perseverance of the Dutch Economy, 1500-1815 (Cambridge: Cambridge University Press, 1997) at 81-91 and 12934.

${ }^{68}$ Raymond de Roover, "Banking and Credit in the Formation of Capitalism", Fifth International Conference of Economic History Leningrad 1970 (Paris, 1979) at 9 [de Rover, "Banking and Credit"]. See in detail, Raymond de Roover, Money, Banking and Credit in Mediaeval Bruges: Italian Merchant Bankers, Lombards and Money Changers: A Study in the Origins of Banking (Cambridge, Mass: The Medieval Academy of America, 1948; republished, London: Routledge/Thoemmes Pres, 1999 as vol. II of The Emergence of International Business, 12001800).

${ }^{69}$ For a detailed analysis in a broad context, see de Roover, "The Organization of Trade" supra note 56 at 42.

70 de Roover identifies three stages in the history of the bill of exchange from its inception to the end of the $18^{\text {th }}$ century: Raymond de Roover, L'Evolution de la Lettre de Change XIV ${ }^{\mathrm{e}}$ - XVIII ${ }^{\mathrm{e}}$ siècles (Paris: Librairie Armand Colin, 1953) at 18-19 [de Roover, lettre de change]. He enumerates two subsequent periods, one of expansion, at the $19^{\text {th }}$ century during which the bill of exchange became discountable, followed by a subsequent contraction in terms of actual use. For the early bill of payment as a notarial instrument, see e.g. André-E Sayous, "L'origine de la lettre de change" (1933) 12 (Ser. 4) Revue historique de droit français et étranger 66; André-E Sayous, "Note sur l'origine de la lettre de change et les débuts de son emploi á Barcelone (XIVe siècle)"'(1934) 13 (Ser. 4) Revue historique de droit français et étranger 315; and André-E Sayous, "Les méthodes commerciales de Barcelone au XVe siècle, d'après des documents inédits de ses archives” (1936)15 (Ser.4) Revue historique de droit français et étranger 255 at 
bankers formed an intercity network that gave rise to the emergence of an elaborate multilateral clearing and settlement arrangement, implemented by them periodically in medieval fairs. ${ }^{71}$

\section{(iii) $\quad$ Post-Medieval Era}

Against this background the modern banking system, accommodating the present payment system, was born in post-medieval England. Its roots are in the institutional transformation of the goldsmiths' system and the establishment of the Bank of England that followed. ${ }^{72}$

The process involved (i) the transformation of the business of individual goldsmiths into that of deposit bankers who accepted deposits, lent out of them, including by discounting bills of exchange, as well as facilitated for depositors' cheque payments out of the deposits; (ii) the existence of a tight network of all such goldsmiths ready to extend credit to each other, so as to allow for reciprocal correspondent banking services facilitating interbank debt clearing and settlement originally on a bilateral and later on a multilateral basis, leading to the establishment of a clearing house, thereby allowing risk reduction, enhanced efficiency, and generating common services that facilitated further development, ${ }^{73}$ (iii) the establishment of the Bank of England, originally as a lender to the government and then, having adopted goldsmiths' practices, gradually evolving in the subsequent two centuries into a modern central bank maintaining settlement accounts for deposit banks (being the successors of goldsmiths) so as to facilitate interbank final settlement as well as to become a lender of last resort; ${ }^{74}$ and (iv) the issuance of banknotes, first as circulating obligations of goldsmiths evidencing either deposits or

274-86 [Sayous, "méthodes commerciales XV"] at 274-86. With the disappearance of the notarial requirement, the instrument nevertheless retained some formal language: Marie-Thérèse Boyer-Xambeu, Ghislain Deleplace \& Lucien Gillard, Private Money \& Public Currencies: The $16^{\text {th }}$ Century Challenge, translated by Azizeh Azodi (New York and London: ME Sharpe, 1994) at 30.

${ }^{71}$ See Boyer-Xambeu et al., supra note 70 at 91-94 as well as at 70-91. See also de Roover, lettre de change, supra note 70 at 74-82; Usher, supra note 6 at 110-33; and Paul-Louis Huvelin, Essai historique sur le droit des Marchés $\&$ des Foires (Paris: Arthur Rousseau, 1897) at 534-93.

72 See e.g. Richard D Richards, The Early History of Banking in England (New York: A.M. Kelley, 1965, reprint of 1929 edition). For a succinct summary, see Holdsworth, supra note 59 at 185-92.

${ }^{73}$ See in detail, Stephen Quinn, "Balances and goldsmith-bankers: the co-ordination and control of inter-banker debt clearing in seventeenth-century London", in David Mitchell, ed, Goldsmiths, Silversmiths and Bankers: Innovation and the Transfer of Skill, 1550 to 1750 (London: Alan Sutton Publishing and Centre for Metropolitan History, 1995) at 53 .

${ }^{74}$ See HV Bowen, "The Bank of England During the Long Eighteenth Century, 1694-1820” in Richard Roberts \& David Kynaston, eds, The Bank of England: Money, Power, and Influence 1694-1994 (Oxford: Clarendon Press, 1995). See also Richard D Richards, "The First Fifty Years of the Bank of England (1694-1744)", in Johannes Gerard van Dillen, ed, History of the Principal Public Banks (London: Frank Cass, 1964, being $2^{\text {nd }}$ impression of the $19341^{\text {st }}$ ed., The Hague: Martinus Nijhoff, 1934) at 201; Richard Roberts, "The Bank of England and the City" in Richard Roberts \& David Kynaston, eds, The Bank of England: Money, Power, and Influence 16941994 (Oxford: Clarendon Press, 1995) at 152, 153. For its origins see also James E Thorold Rogers, The First Nine Years of the Bank of England (Oxford: Clarendon Press, 1887). 
loans, then as paper money issued by the goldsmiths, and ultimately, as paper money, 'legal tender', exclusively issued by the Bank of England. ${ }^{75}$

Both correspondent banking and customer payment activity required intensive monitoring by the goldsmith-bankers. In turn, this facilitated credit decision-making and led to specialization in advancing information-intensive non-traded loans. Such lending became a principal niche for a profitable commercial banking business as well as effective financial intermediation for the economy as a whole. In providing such loans, as well as in issuing banknotes and discounting bills of exchange, the goldsmith-bankers came to provide a reliable source of liquidity to the economy.

For its part, in departing from the model of the earlier Continental public bank, the Bank of England complemented private commercial banks without competing with or endeavouring to substitute for them. Rather, being their bank maintaining for them accounts, ${ }^{76}$ it became able to furnish them with a source of liquidity so as to be a lender of last resort. As well, it provided them with the efficiency of multilateral settlement in reserve accounts held with it. In both ways, it gradually became as a 'central bank' an integral part of the private bank network. ${ }^{77}$

The banknote was issued first by the goldsmith-banker, ${ }^{78}$ originally possibly as a 'warehouse receipt' for deposited coins, and certainly against a fractional reserve of coins or metal. ${ }^{79}$ The power to issue banknotes was taken over by the Bank of England, ${ }^{80}$ with convertibility ultimately ceasing to exist altogether in the course of the 20 th century. ${ }^{81}$ Using

\footnotetext{
${ }^{75}$ Notes of the Bank of England were made legal tender in England and Wales for all payments (except for by the Bank itself) over five pounds by s. 6 of the Bank of England Act, 1833, (U.K.), 3 \& 4 Will. IV, c. 98.

${ }^{76}$ While certainly there was rivalry the fact is that "many goldsmiths opened accounts with the Bank within a few months of its creation"; James Milnes Holden, The History of Negotiable Instruments in English Law (Homes Beach Fla: WM W. Gaunt \& Sons, Reprint 1993 of 1955 edition by Athlone Press) at 93.
}

\footnotetext{
${ }^{77}$ See e.g. Ben Norman, Rachel Shaw \& George Speight, "The history of interbank settlement arrangements: exploring central banks' role in the payment system" (2011) Bank of England, Working Paper No 412, online: <https://www.ecb.europa.eu/home/pdf/research/Working_Paper_412.pdf>, accessed 27 December 2017.
}

78 See e.g. Richard D Richards, The Early History of Banking in England (New York: A.M. Kelley, 1965, reprint of 1929 edition) at 40-43 [Richards, Early History]; Holden, supra note 76; Albert Feavearyear, The Pound Sterling: A History of English Money, 2nd ed by EV Morgan (Oxford: Clarendon Press, 1963) at 107-08; JK Horsefield, "The 'Stop of the Exchequer' Re-visited" (1982), 35 Economic History Review 511 at 523 [Horsefield, "Exchequer"]; Tassell and Lee v. Lewis (1695), 1 Ld. Raym. 743 at 744, 91 E.R. 1397 at 1398 (K.B.).

\footnotetext{
${ }^{79}$ Notes were issued by banks either against deposit of specie, that is, precious metal or coins, or against the negotiation, and hence in discount, of bills of exchange, as well as of promissory notes; Smith, supra note 66; George Tucker, The Theory of Money \& Banks Investigated (New York: AM Kelly, 1964, reprint of 1839 original) at 161,164 .

${ }^{80}$ See e.g. Holden, supra note 76 at 92

${ }^{81}$ Convertibility was abolished for good in the UK under the Gold Standard (Amendment) Act, 1931, 21 \& 22 Geo. V, c. 46.
} 
funds on deposit at the central bank, private banks buy banknotes from the central bank and sell them for use to the public, against funds held by its members on deposit with private banks. As they are exchanged out of and back into deposits "according to customer payment habits," as a form of cash, banknotes (together with coins), are not the principal form of money, a role now preserved to scriptural money. ${ }^{82}$

The integration of banks into a banking network, consisting of commercial banks multilaterally clearing in a clearinghouse ${ }^{83}$ and settling on the books of the central bank which is an integral part of this network, has led to a fundamental albeit subtle change in the mode of the creation of money through 'banking'. Thus, deposits made to commercial banks are typically not anymore in the form of specie or commodity money. Rather, they are primarily created by lending into customers' deposit accounts. For its part, an addition to bank's liquid assets is typically made not in the form of specie or commodity money, but rather in the form of an increase in the sum credited to that bank's own account; at least for a large bank such increase is in the credit to its account with the central bank. ${ }^{84}$ Other than by receiving an interbank payment, liquidity designed to meet deposit obligations is obtained at least by a large commercial bank, in the form of credit posted to its account with the central bank, through borrowing in an interbank market, selling government securities, or as a last resort, borrowing from the central bank. At the same time, non-cash payment activity continues to be primarily carried out over deposit accounts held in commercial banks. Monitoring depositors' payment activity in accounts continues to facilitate credit decision-making and lead to specialization in advancing information-intensive non-traded loans, so as to continue to be a principal niche for a profitable commercial banking business as well as effective financial intermediation for the economy as a whole. ${ }^{85}$ This must be true also in an era where credit information may be available from other sources such as credit bureaux.

The architecture, instruments and institutions of the English system spread globally. At present, commercial banks take deposits from the public, lend into customers' deposit accounts, and provide payment services in conjunction with deposit accounts. In each country, at least all major commercial banks clear multilaterally and settle over deposit accounts they hold with the

\footnotetext{
${ }^{82}$ Joseph Huber, “The Chicago Plan (100\% Reserve) and Plain Sovereign Money” (January 2015), online: $<$ http://www.academia.edu/31071041/The_Chicago_Plan_100_Reserve_and_Plain_Sovereign_Money>, accessed 28 December 2017.

${ }^{83}$ For the origins and early history of the London Clearing House see e.g. William Howarth, Our Clearing System and Clearing Houses (London: Effingham Wilson, 1884); and Phillip W Matthews, The Bankers' Clearing House: What it Is and What it Does (London: Pitman \& Sons, 1921). For a modern perspective on the scope of operation of a clearing house, see e.g. Herbert L Baer, Virginia G France \& James T Moser, "What Does a Clearinghouse Do?" (Spring 1995) 1 Derivatives Quarterly 39. See also: James T Moser, "What is multilateral clearing and who cares?" Chicago Fed Letter, Nov. 1994 (No. 87, Federal Reserve Bank of Chicago).

${ }^{84}$ See Michael McLeay, Amar Radia and Ryland Thomas, "Quarterly Bulletin 2014 Q1: Money creation in the modern economy" (2014) Bank of England, online: <https://www.monetary.org/wpcontent/uploads/2016/03/money-creation-in-the-modern-economy.pdf>, accessed 27 December 2017.

${ }^{85}$ Goodfriend, supra note 10 at 252-57.
} 
central bank. ${ }^{86}$ They also maintain correspondent relationships ${ }^{87}$ with local small banks as well as with cross-border or overseas large banks, so as to create a global network over which in principle non-cash payments can be made by any account holder to another in any currency. Moreover, as a rule, paper money in the form of banknotes is issued in each country by its central bank.

Banknotes, together with coins for small change, constitute cash (or currency). Payment in cash is typically made face to face, without any intermediation. Noncash payments, whether face to face or between distant parties, require intermediation. Where payer and payee hold their respective accounts with the same bank a noncash payment is carried out by that bank debiting the payer's account and crediting that of the payee. Where payer and payee hold their respective accounts at two banks which are correspondents a noncash payment involves debiting the payer's account by the payer's bank, crediting the payee's account by the payee's bank, and either debiting the account of the payer's bank by the payee's bank or crediting the account of the payee's bank by the payer's bank. In a domestic payment system, at least all major banks hold their accounts with the central bank so that the interbank component of payment between two such banks is carried out as part of the multilateral interbank settlement on the books of the central bank. Otherwise, a noncash payment requires a chain of settlements on correspondent accounts, with or without settlement on the books of the central bank, or alternatively, one settlement between correspondent banks followed by another settlement on the books of a central bank. To take a simple example for the latter, the interbank component of a noncash payment in Australian currency from a customer of Bank A in Canada to a customer of Bank B in Australia, assuming that the two are non-correspondent major banks, is carried out by Bank A using its correspondent, another Australian major bank, which in turn, settles with Bank B on the books of the central bank of Australia.

Three principal features characterize payment services facilitated by the modern banking system. First, value held on deposit with participating banks, often referred to as 'bank money' or more specifically, 'commercial-bank money', is denominated in and is redeemable to fiat money (or banknotes), that is, an official currency or 'legal tender'. Second, such value is in the form of a claim in an account maintained with a bank. Typically, this is an asset account; however, payment may be made by means of a credit card, in which case payment is carried from the payer's credit account rather than asset account having a positive balance in bank money. Also in such a case, payment results in an increase in the sum of bank money available to the payee in the payee's asset account—while the payer becomes obligated to reimburse the payer's bank, typically (if not exclusively) in bank money (originating from the payer's asset account). Third, claims against the central bank, often referred to as claims to 'central-bank

\footnotetext{
${ }^{86}$ CPSS, Core Principles for Systemically Important Payment Systems (Basel: BIS, January 2001) at 34-36, online: $<$ https://www.bis.org/cpmi/publ/d43.pdf>, accessed 27 December 2017.

${ }^{87}$ See in general, CPMI, Correspondent Banking (Basel: BIS July 2016) online: <https://www.bis.org/cpmi/publ/d147.pdf>, accessed 27 December 2017.
} 
money', are available both to holders of fiat money/banknotes and the banks. ${ }^{88}$ The latter multilaterally settle their reciprocal claims on the books of the central bank. Obligations on bank deposits payable on demand are referred to as 'scriptural money', being a category covering both commercial and central bank money. ${ }^{89}$

The non-cash payment system is then premised on the use of 'scriptural money.' Its architecture is centralized. Thereunder, a bank maintains deposit accounts for customers (who thus keep with it commercial bank money). For its part, a large bank may also maintain deposit accounts (in commercial bank money) for correspondent banks. Finally, the central bank maintains settlement (deposit) accounts at least for large banks (which thus hold with it central bank money). ${ }^{90}$ As a whole, the system can be visualized as a pyramid at whose head or apex stands the central bank with which at least large banks hold accounts, and possibly with small banks holding accounts with large banks. Individual and corporate customers are at the bottom or base of the pyramid holding their accounts in banks (whether large or small). ${ }^{91}$

\section{The coming of the cyber age: Electronic payments, e-money, access to central bank balances, the blockchain, and digital currencies}

\section{(i) The advent of electronic banking and e-money}

Historically, payment instructions accessing bank money were either oral or, more typically, in writing. Use of telecommunication, first the telegraph and then the transatlantic cable, goes back to mid- $19^{\text {th }}$ century ${ }^{92}$ However, the watershed of electronic banking, where payments are processed as well as transmitted electronically, is a development of the second part of the $20^{\text {th }}$ century. Once it became possible to transmit instructions electronically, from a computer or computer terminal, the electronic funds transfer was born. Telecommunication in

\footnotetext{
${ }^{88}$ For the distinction between 'commercial-bank money' and 'central-bank money' see e.g. Mark Manning, Erlend Nier \& Jochen Schanz, eds, The Economics of Large-value Payments and Settlement: Theory and Policy Issues for Central Banks (Oxford: Oxford University Press, 2009) at 4.

${ }^{89}$ For this term see: Antonio Sáinz de Vicuña, "An Institutional Theory of Money”, in Mario Giovanoli and Diego Devos, eds, International Monetary and Financial Law: The Global Crisis (Oxford: OUP, 2010) at 517 and 527.
${ }^{90}$ On moving away from this tiering structure see e.g. Evangelos Benos, Gerardo Ferrara and Pedro Gurrola-Perez, "The impact of de-tiering in the United Kingdom's large-value payment system" (2017) Bank of England, Working Paper No 676.

${ }^{91}$ See e.g. E Gerald Corrigan, "Luncheon Address: Perspectives on Payment System Risk Reduction”, in David B. Humphrey, ed, The U.S. Payment System: Efficiency, Risk and the Role of the Federal Reserve (Boston: Kluwer Academic Publishers, 1990) at 129-130. See also Hans J Blommestein \& Bruce J Summers, "Banking and the Payment System", in Bruce J Summers, ed, The Payment System: Design, Management and Supervision (Washington: International Monetary Fund, 1994) at 15 and 27; and Bruce J Summers, "The Payment System in a Market Economy", in Summers, ibid, at 1-5.

${ }^{92}$ See Douglas W Arner, Janos N Barberis \& Ross B Buckley, "The Evolution of Fintech: A New Post-Crisis Paradigm?" at 4, online: <https://papers.ssrn.com/sol3/papers.cfm?abstract_id=2676553>, accessed 28 December 2017.
} 
the electronic age was originally on cable or wire; ${ }^{93}$ subsequently the wireless option became available, ${ }^{94}$ and ultimately, instructions could be transmitted over the Internet. ${ }^{95}$

Developments have not been limited to communication. It became also possible to 'load' monetary value (that is, value denominated in an official or, in fact, any unit of account) on a stored-value device such as a card or personal computer. In such a case, the value became known as 'electronic money' or 'e-money'. The majority of e-money schemes have involved 'balancebased" products. In such products, devices store and manipulate a numeric ledger, with transactions performed as debits or credits to a balance. Accordingly, this type of e-money is a monetary balance or value recorded electronically on and is available from a stored-value product $(S V P)$, such as a chips card, or a hard drive in a personal computer, or a server. ${ }^{96}$ Such a record, accessible from the device without resort to the bank's computer system, can be viewed as a decentralized bank account. ${ }^{97}$ Under a variant of the aforementioned product, monetary value is not loaded on the device; rather, it is available from a master account, belonging to the issuer or someone acting on the issuer's behalf. However, as in the case of e-money, monetary value is not available from the payer-debtor's own bank account. ${ }^{98}$

Prepaid value is in a bank account, even if not that of the payer. But also, e-money is ultimately a variant of 'bank money'; 99 thus, whether e-money is purchased in cash or by means of a debit to the purchaser's bank account, the issuer has its own bank account credited with the amount sold to the purchaser. Where the e-money is purchased from a bank the account credited is the reserve account of the selling bank. Payment in e-money is forwarded to the payee's bank which credits the payee's account with the amount of payment and forwards the e-money itself

\footnotetext{
${ }^{93}$ For an early discussion on the subject see Israel Sendrovic, “Technology and the Payment System”, in Summers, supra note 91 at 178.

${ }^{94}$ See Gianni Bonaiuti, "Economic Issues on M-Payments and Bitcoin” in Gabriella Gimigliano, ed, Bitcoin and Mobile Payments Constructing a European Union Framework (London: Palgrave, 2016) at 27.
}

${ }^{95}$ See CPSS, Innovations in retail payments (Basel: NIS, May 2012), online:

$<$ https://www.bis.org/cpmi/publ/d102.pdf>, accessed 27 December 2017. See also: CPSS, Survey of developments in electronic money and internet and mobile payments (Basel: BIS, March 2004), online:

$<$ https://www.bis.org/cpmi/publ/d62.pdf>, accessed 27 December 2017.

${ }^{96}$ CPSS, Security of Electronic Money (Basel: BIS, 1996) particularly at 5, online:

$<$ https://www.bis.org/cpmi/publ/d18.pdf>, accessed 27 December 2017. See also information on 'electronic money' at <https://en.wikipedia.org/wiki/Electronic_money>, accessed 27 December 2017.

${ }^{97}$ Alan L Tyree, "The Legal Nature of Electronic Money” 10 Journal of Banking and Finance Law and Practice 273 at $276(1999)$.

${ }^{98}$ Unfortunately, the confusion between these two types of payment products is rampant. For a definition of 'emoney' that does not include the prepaid product, see Ben Fung, Miguel Molico and Gerald Stuber, "Electronic Money and Payments: Recent Developments and Issues" (2014) Bank of Canada Discussion Paper 2014-2, online: <http://www.bankofcanada.ca/wp-content/uploads/2014/04/dp2014-2.pdf>, accessed 27 December 2017.

${ }^{99}$ I thus disagree with the classification of CPMI, Digital Currencies (Basel: BIS, November 2015) at 6, online: https://www.bis.org/cpmi/publ/d137.pdf, accessed 11 March 2018, under which e-money is lumped with digital currencies as "E-money (broad sense)" so as to be contrasted with commercial bank money. 
for redemption against the value previously credited to the seller's account. In the final analysis, even where pre-paid value or e-money is not issued by a bank, a scheme must facilitate the purchase and redemption through banks.

For its part 'electronic banking' enhanced payment services in several other ways. First, it introduced electronic processing also to paper-based instruments such as cheques. ${ }^{100}$ Second, it facilitated new as well as variations of existing products. ${ }^{101}$ Third, new players, such as money transmitters ${ }^{102}$ or payment institutions, ${ }^{103}$ and e-money institutions ${ }^{104}$ entered the scene as endpayment institutions in a payment transaction, facilitating domestic and international payments in small amounts to parties who do not have bank accounts. Fourth, the power balance in the partnership between financial institutions and telecommunication carriers has shifted, allowing the latter a greater voice and share in the payment market. ${ }^{105}$ Fifth, in facilitating instant communication, electronic banking allowed the use of risk reduction methods as well as instant authorization leading to an immediate final credit to the payee's account way ahead of the interbank settlement; such may be the case in domestic large value wholesale payment

\footnotetext{
${ }^{100}$ See in general e.g. Benjamin Geva, "Is Death of the Paper Cheque Upon Us? The Electronic Presentment and Deposit of Cheques in Canada" (2014) 30 BFLR 113; and Benjamin Geva, "From Paper to Electronic Order: The Digitalization of the Check in the USA" (2015) 4 Penn State Journal of Law and International Affairs 96.
}

${ }^{101}$ Such as preauthorized debits ('PADs') replacing the delivery of a series of post dated cheques; the debit card complementing the credit card and to a large extent substituting both cash and cheques; preauthorized credits ('PAPs') substituting paycheques.

102 See e.g. Section 102 (14) of the Uniform Money Services Act (UMSA), online:

<http://www.uniformlaws.org/shared/docs/money\%20services/umsa_final04.pdf>, accessed 28 December 2017, under which "Money transmission" is defined to mean "selling or issuing payment instruments, stored value, or receiving money or monetary value for transmission..."

${ }^{103}$ Defined in Article 4 (4) of the Directive (EU) 2015/2366 of the European Parliament and of the Council of 25 November 2015 on payment services in the internal market, amending Directives 2002/65/EC, 2009/110/EC and 2013/36/EU and Regulation (EU) No 1093/2010, and repealing Directive 2007/64/EC, Official Journal of the European Union 23.12. 2015, L 337/35, online: <http://eur-lex.europa.eu/legal-

content/EN/TXT/?uri=celex:32015L2366>, accessed 28 December 2017 to mean: "a legal person that has been granted authorisation in accordance with Article 11 to provide and execute payment services throughout the [European] Union." The term does not include credit institution (bank), electronic money institution, or post office giro institutions. See Article 1(1).

${ }^{104}$ Defined under Article 2(1) of the DIRECTIVE 2009/110/EC of the European Parliament and of the Council of 16 September 2009 on the taking up, pursuit and prudential supervision of the business of electronic money institutions amending Directives 2005/60/EC and 2006/48/EC repealing Directive 2000/46/EC, Official Journal of the European Union, 10.10. 2009. L 267/7, online: <http://eurlex.europa.eu/legalcontent/EN/TXT/?uri=CELEX\%3A32009L0110>, accessed 27 December 2017, to mean: "a person that has been granted authorisation under Title II to issue electronic money."

105 See e.g. document issued by the Canadian Bankers Association (CBA), Canadian NFC Mobile Payments Reference Model, Version 1.03, 14 May 2012, online:

<https://www.cba.ca/Assets/CBA/Files/Article\%20Category/PDF/msc_20120514_mobile_en.pdf>, accessed 28 December 2017 
systems ${ }^{106}$, and retail fast payments networks. ${ }^{107}$ This is also the case in a typical credit card payment, even when it is carried internationally. ${ }^{108}$

Indeed, electronic banking facilitated branchless banking to the detriment of banks with a large branch network. ${ }^{109}$ As well, possible impact of electronic banking on monetary policy has been fiercely debated. ${ }^{110}$ At the same time, none of the various facets of electronic banking has affected the architecture of the payment system even as it expanded its scope and globalized it. No wonder, the law governing wireless instructions is the same as the one governing wire orders. ${ }^{111}$ For their part, money transmitters, payment institutions as well as e-money institutions have been using banks as intermediaries in the transfers in which they participate at either end of the transaction. ${ }^{112}$ They thus increased rather than decreased payment intermediation.

Furthermore, not treating such institutions as deposit takers hinges on a 'benevolent' strict view of 'deposit taking' so as to exclude the delivery of money for a specific purpose. ${ }^{113}$ True, a payment instruction issued from a digital device such as a mobile phone rather than from a computer terminal or computer is often said to result in a mobile payment. When the payment scheme is operated over mobile devices it is even described as involving 'mobile money'. However, in substance, payment orders initiated from a digital or mobile device is a specie of an electronic funds transfer. ${ }^{114}$ For its part 'mobile money' is a form of 'e-money'. It is therefore

\footnotetext{
${ }^{106}$ See e.g. the large value wholesale payment system in Canada where finality of payment is guaranteed by the central bank prior to the completion of settlement. CPSS, Core Principles for Systemically Important Payment Systems (Basel: BIS, January 2001) at 30, online: <https://www.bis.org/cpmi/publ/d43.pdf>, accessed 28 December 2017.
}

${ }^{107}$ See e.g. CPMI, Fast payments -Enhancing the speed and availability of retail payments (Basel: BIS, November 2016), online: <https://www.bis.org/cpmi/publ/d154.pdf>, accessed 28 December 2017.

${ }^{108}$ For the legal nature of the credit card payment see in general: Benjamin Geva, "The Processor and the Contractual Matrix in a Card Scheme: How Privity Fell and Resurrected in Aldo v. Moneris" (October 2013) 32:5 Nat'l Banking L Rev 73.

${ }^{109}$ Hanno Beck, "Banking is essential, banks are not. The future of financial intermediation in the age of the Internet" (2001) 3:7-22 Economic Research and Electronic Networking, online:

$<$ https://link.springer.com/content/pdf/10.1023\%2FA\%3A1009927623530.pdf>, accessed 9 January 2018.

${ }^{110}$ See e.g. Benjamin J Cohen, “Electronic money: New day or false dawn?” (2001) 8:2 Review of International Political Economy 197, online:

<https://www.researchgate.net/publication/233010154_Electronic_money_New_day_or_false_dawn>, accessed 9 January 2018.

111 See e.g. Benjamin Geva, "The Wireless Wire: Do M-Payments and UNCITRAL Model Law on International Credit Transfers Match?” (2011) 27:2 BFLR 249.

112 See e.g. CPSS and the World Bank, General principles for international remittance services (Basel: BIS and the World Bank, January 2007), online: <https://www.bis.org/cpmi/publ/d76.pdf>, accessed 28 December 2017.

${ }^{113}$ For a critical analysis see e.g. Benjamin Geva and Muharem Kianief, "Reimagining E-Money: Its Conceptual Unity with Other Retail Payment Systems" (2005) 3 Current Developments in Monetary and Financial Law 669 and 677-79.

${ }^{114}$ Whether from (or into) an asset account, credit line, or stored-value — as the case may be. 
confusing to treat such developments as reflecting a "digitization of state-issue currenc[y]" even in connection with an on-line (e-commerce) transaction. ${ }^{115}$ Ultimately efficiency is bound either to turn payment institutions into banks or for banks take over payment institutions, either directly or as subsidiaries, so as to eliminate this unnecessary layer of intermediation. The issue for banks is the adoption of a different level of service rather than the elimination of banks as an essential component in linking between payers and payees.

The broader question however is whether 'electronic banking' has not been superseded by 'Fintech,' 'snatching' money and payments from the banking system. Fintech refers to the use of technology by IT firms ${ }^{116}$ to deliver financial solutions directly to purchasers of financial products such as payment services. ${ }^{117}$ Technology designed to deliver financial solutions is however available also to banks whether directly or indirectly by purchase from IT firms. The thesis of this paper is that the function of banks as deposit takers as well as the existence of a bank network provide banks an edge in competing with IT firms in delivering payment services to the public. By comparison to those provided by banks, payment means and methods that purport to bypass the banking system are inherently inadequate.

For sure, there is nothing to preclude IT firms from becoming banks and competing with existing banks on equal footing. Indeed, in Antiquity and the Middle Ages it was the money changer who became a deposit banker. In the Middle Ages it was the large merchant who made and received intercity commercial payments. Subsequently, it was the goldsmith who became a banker in post-Medieval England. According to this logic, there is nothing new in the transformation of the IT firm into a bank; the IT firm merely goes in the footsteps of other professionals who became bankers. This is true and yet it does not convey the full picture. With their transformation into bankers, the moneychangers, intercity merchants and goldsmiths created a new space, heretofore neither known nor occupied. In contrast, 'banking' is now a well-defined industry: technology is not something new for banks; they have been developing as well as purchasing it for awhile. Hence the idea that banks will unfold and become extinct like dinosaurs is unfounded. IT firms turning banks join an existing and well-functioning network rather than supersede its existing members. To fully defeat incumbents, IT firms must develop a model different than that of 'banking'; the ensuing discussion is designed to disprove the adequacy if not the existence of such a model.

\footnotetext{
115 Notwithstanding Joshua S. Gans and Hanna Halaburda, "Some Economics of Private Digital Currency" (2013) Bank of Canada, Working Paper 2013-38, online: <http://www.bankofcanada.ca/wpcontent/uploads/2013/11/wp2013-38.pdf>, accessed 28 December 2017.

${ }^{116}$ Generally speaking, IT "deals with the technology part of any information system, and as such deals with hardware, servers, operating systems and software etc." See e.g. <http://www.differencebetween.com/difference-betweeninformation-systems-and-vs-information-technology/>, accessed 28 December 2017.

${ }^{117}$ A broader definition under which Fintech "refers to the use of technology to deliver financial solutions", as in at 6, will encompass the use of technology by banks such as in electronic banking, and hence is unhelpful for the purposes of this paper.
} 
In reviewing the present architecture of the payment system prior to the Fintech era Goodfriend opined that "... although valuing deposits at par and holding fractional reserves is efficient for individual banks, it had the potential for generating destabilizing systemwide bank runs." In his view this risk is however "remedied efficiently by central bank monetary policy,"118 as well as by other payment system policies. ${ }^{119}$ Conversely, reviving and building on old ideas, ${ }^{120}$ a recent set of proposals will make central bank money deposits available to the public either directly or indirectly. A typical rationale, premised on new technological developments, is that:

Central banking evolved at a time when service provision in local branches was integral to providing banking services. In that world it made sense for the central bank to 'wholesale' its core exchange settlement and liquidity support services to banks which would then 'retail' them to individuals and businesses via their branches, passbooks and cheque accounts. It was impracticable for central banks' services to be provided to individuals.

At the same time, the rationale goes on, "[m]odern technology enables us to extend some core central banking services to individuals and businesses." 121

One proposal premised on this rationale is the provision of payment services to the public exclusively by a designate government agency that will take deposits from the public but will have restricted investment powers so as to be able to invest only in safe assets such as supercollateralized real estate mortgages. Under that proposal, payment transactions will be carried out over deposit accounts with respect to which the liability of the depositary (the government agency) is effectively secured by investment in high quality assets. On this basis, such deposits will benefit from unlimited guarantee of the central bank. Under that proposal, commercial banks will be able to lend to customers and sell them investment products but be precluded from providing payment services. ${ }^{122}$

However, one may reasonably suppose that in upsetting the delicate balance between the roles of the public and private sectors in the monetary and payment systems, this proposal will be

\footnotetext{
${ }^{118}$ Goodfriend supra note 10 at 248.

${ }^{119}$ Goodfreind, ibid at 261.

${ }^{120}$ For detailed discussions see references in sources cited in notes 126 and 127 infra.

${ }^{121}$ Nick Gruen, Central Banking for all: A Modest Proposal for Radical Change (London: Nesta, March 2014) at 7 , online: https://www.nesta.org.uk/sites/default/files/central_banking_for_all.pdf, accessed 28 December 2017.

${ }^{122}$ Ibid, passim. In the UK, he designates the National Savings and Investments (NS\&I) as the appropriate governmental agency. At the moment the NS\&I accepts deposits from the public (up to prescribed ceilings) and places them in savings accounts from which payment services cannot be provided. In Gruen's words, "what is being proposed is to allow super-collateralised loans to be treated as part of the monetary system rather than the financial system." Ibid at 9.
} 
perceived as going too far (or in fact, nowhere). Certainly, in monopolizing payment services in the hands of a government agency, the proposal will stifle competition and give no incentive to innovate. Furthermore, the proposal is not persuasive in mandating central bank guarantee on the top of the requirement to invest deposited funds in safe assets. I therefore doubt that in a capitalist economy that proposal will persuade policy makers. At the same time, unclothing it from these objectionable elements, the proposal is a reminiscent of an earlier idea, that of 'narrow banking'; thereunder payment transactions are carried out over bank deposits of which the proceeds are invested in safe assets. ${ }^{123}$ 'Narrow banking' does not require the superimposition of central bank guarantee and in fact does not alter the traditional roles of commercial banks as deposit takers, providers of payment services, and lenders.

Under another proposal the central bank will open accounts and offer payment services directly to the public. This proposal is however said to impose "a large administrative burden" on the central bank that "could distract it from its other functions in [regulating] and managing monetary policy." It is further acknowledged that under the proposal the central bank, "a stateowned enterprise," would undertake pure market functions, in which it "would have no commercial incentive to innovate [payment] services." 124 To meet these objections, under a variant, it is proposed that public access to scriptural central bank money or its equivalent will be indirect. ${ }^{125}$

There are however two alternative approaches to such a variant. One is premised on 'full reserve banking' ${ }^{126}$ while the other is of 'plain sovereign money'. ${ }^{127}$ Briefly stated, under the former, the entire quantity of commercial bank money, namely, the total amount of demand deposits with banks, is to be backed by $100 \%$ reserve of central bank money held by commercial banks on deposit with the central bank. ${ }^{128}$

123 The term is said to be coined by Robert Litan, What Should Banks Do? (Washington, DC: Brookings Institution, 2005). See Patrizio Lainà, "Proposals for Full-Reserve Banking: A Historical Survey from David Ricardo to Martin Wolf", Economic Thought 4:2 (2015) at 12, online: <http://et.worldeconomicsassociation.org/files/WEA-ET-4-2Laina.pdf>, accessed 28 December 2017. Litan discusses 'narrow banking' ibid at 6, 169-178 and 186-87.

124 Ben Dyson \& Graham Hodgson, Digital Cash: Why Central Banks Should Start Issuing Electronic Money (London: Positive Money, 2016) at 15, online: <http://positivemoney.org/wpcontent/uploads/2016/01/Digital_Cash_WebPrintReady_20160113.pdf>, accessed 28 December 2017.

${ }^{125}$ Dyson and Hodgson, ibid at 16.

${ }^{126}$ See e.g. Jaromir Benes and Michael Kumhof, "The Chicago Plan Revisited” (2012) International Monetary Fund, Working Paper WP/12/202, online: <https://www.imf.org/external/pubs/ft/wp/2012/wp12202.pdf>, accessed 28 December 2017; William R Allen, "Irving Fisher and the 100 Percent Reserve Proposal" (1993) 36:2 Journal of Law and Economics 703, online: <http://www.journals.uchicago.edu/doi/pdfplus/10.1086/467295>, accessed 28 December 2017; and Lainà, supra note 123.

${ }^{127}$ See e.g.: Huber, supra note 82; Phillipe Bacchetta, The Sovereign Money Initiative in Switzerland: An Economic Assessment (26 September 2017), online: <https://people.unil.ch/philippebacchetta/files/2017/06/Vollgeld_5.pdf>, accessed 28 December 2017. For a blueprint see Ben Dyson, Graham Hodgson \& Frank van Lerven, Sovereign Money - An Introduction (London: Positive Money, 2016), online: <http://positivemoney.org/wpcontent/uploads/2016/12/SovereignMoney-AnIntroduction-20161214.pdf>, accessed 28 December 2017.

128 There are at least two variants as to the rules which will govern the conduct of monetary policy under such a regime, particularly as to the role of discretion by the central bank. For a summary see Huber, supra note 82 at 3 . 
Under the latter, that of 'plain sovereign money,' ${ }^{129}$ the distinction between the two types of scriptural money is abolished; what exists is only one category of scriptural money, central bank money. ${ }^{130}$ It will be available to members of the public in accounts on the books of the central bank; unless operated by the central bank itself, as discussed above, such accounts will be operated through and managed by commercial banks, ${ }^{131}$ possibly in 'transaction accounts' 132 which will be distinguished from 'investment accounts' of which funds may be invested in designated collections of assets of a broadly similar risk profile. Each investment fund will be a distinct legal and corporate entity. Lending will be carried out of investment funds (possibly as well as from long-term borrowing from the public) and should not create additional money or purchasing power. ${ }^{133}$ Investment account holders will bear the risk of non-payment on due date, and not being available to them prior to that, sovereign money owed to them will not serve as commercial bank money. Rather, prior to maturity on the investment account, sovereign money deposited in them will be lent by the bank and thus will exclusively be used by borrowers from the bank. ${ }^{134}$ Banking will thus fully reclaim its function as an intermediation between savers and borrowers.

Under both approaches commercial banks will cease to create money by lending into customers' deposits. Money creation will be under the exclusive power of the central bank ${ }^{135}$

\begin{abstract}
${ }^{129}$ Beware of inconsistent use of terminology. Andrew Jackson, Sovereign Money - paving the way for a sustainable recovery (London: Positive Money, November 2013), online: <https://positivemoney.org/wpcontent/uploads/2013/11/Sovereign-Money-Final-Web.pdf $>$, accessed 28 December 2017, uses the term to denote central bank money distributed directly to business to fund infrastructure projects.
\end{abstract}

${ }^{130}$ However, it does not make sense to me to have a hybrid system under which scriptural money is available to the public in both commercial and central bank money as I read Dyson \& Hodgson supra note 124 at 28-30 to suggest.

${ }^{131}$ For a precedent from Sri Lanka, albeit for investors' securities accounts operated by intermediaries on the books of the central bank, see Payment \& Settlement Systems Act, No. 28 of 2005, Chapter II Securities Accounts (Secs 610), online: <http://www.cbsl.gov.lk/pics_n_docs/09_lr/_docs/acts/Paymt_\&_setmt_sys_act.pdf >, accessed 28 December 2017.

${ }^{132}$ For these two options see Michael D Bordo and Andrew T Levin, "Central Bank Digital Currency and the Future of Monetary Policy" (2017) NBER, Working Paper 23711, online: <http://www.nber.org/papers/w23711>, accessed 28 December 2017.

${ }^{133}$ Where required to meet demand further, lending may be done by the creation of new money by the central bank to be lent to banks and other lending institutions for the purposes of relending it to borrowers in the real economy. See Dyson, Hodgson \& van Lerven, supra note 127 at 36.

${ }^{134}$ Legally of course on maturity of the investment account the bank will be liable to depositors and investors regardless of possible default by borrowers, in which case it will be up to the bank to find sovereign money from other sources to fund its liability to depositors and investors.

${ }^{135}$ In connection with sovereign money see e.g. Dyson, Hodgson and van Lerven, supra note 127 at 28-37. One proposal for full reserve banking is for the central bank to act as a 'currency board' in issuing new money only against a basket of available assets (of which gold is only one); see Warren Coats, "My Political Platform for the Nation - 2017' (31 December 2016), Warren's space (blog), online:

<https://wcoats.wordpress.com/2016/12/31/my-political-platform-for-the-nation-2017/>, accessed 28 December 2017 (see section on Monetary and Financial Policies); Warren Coats, "Real SDR Currency Board" (2011) 22:2 Central Banking Journal, online: <https://works.bepress.com/warren_coats/25/ $\geq$, accessed 28 December 2017. 
with commercial banks either being limited to issue its 'replication' or 'shadow' to the public, but not expand its quantity (under the full reserve banking alternative), or being restrained from issuing it at all (under the plain sovereign money alternative). ${ }^{136}$ They will however be able to lend and provide payment services.

An analysis of the pros and cons of each alternative, vis-à-vis each other as well as by reference to the current fractional reserve regime, is beyond the scope of this paper as well as of the competence of this author. At the same time, in relation to the topic at hand, under both alternative banks will continue to accept deposits, make loans (albeit not out of demand deposits), and provide payment services. For sure, they may face competition from 'payment institutions' that do not provide 'investment accounts' services as well as lenders providing 'investment accounts' but not 'payment accounts.' However, it is reasonable to expect that such competitors will be regulated, respectively on the payment, and saving and lending sides, so it will be for banks to leverage the combined services they give to their advantage. For example, as now, monitoring the payment activity of a customer will help a bank in making its lending decision regarding that customer. Hence, a reform under any of these lines will not change the role of commercial banks in the payment system.

What may however change is the legal underpinning of the bank's liability for money deposited in the payments or transactions account. At the moment, a bank is liable to a depositor on a simple debt since money deposited belongs to the bank which can use it as it wishes. ${ }^{137}$ Conversely, under a 'full reserve banking' scheme, the bank's obligation may be conceptualized by analogy to that of a securities intermediary that under Article 8 of the Uniform Commercial Code in the United States ${ }^{138}$ as well as under the Uniform Securities Transactions Act in Canada. ${ }^{139}$ According to this legislation, under the 'indirect holding' regime, a securities intermediary is liable to an investor on a 'securities entitlement' against which the securities intermediary must maintain $100 \%$ 'financial asset'. ${ }^{140}$ At the same time, under a 'plain sovereign money' regime the customers will be entitled from their banks under an 'irregular deposit' which

\footnotetext{
${ }^{136}$ For the view that "both logically and according to the International Accounting Standards, sovereign money cannot be considered to be a debt of the state. Instead, sovereign money conforms to the classification of equity," see Ben Dyson \& Graham Hodgson, Accounting for Sovereign Money: Why State-Issued Money is Not 'Debt' (London: Positive Money, 2016) at 9, online: <http://positivemoney.org/wpcontent/uploads/2016/03/AccountingForSovereignMoney_20160309.pdf>, accessed 28 December 2017.

${ }^{137}$ The locus classicus for this proposition is Foley v. Hill (1848), 2 HLC 28, 9 ER 1002.

${ }^{138}$ See Uniform Commercial Code (UCC) Article 8 (1994) Sections 8-501 to 8-511, in conjunction with definitions in Section 8-102, online: <https://www.law.cornell.edu/ucc/8>, accessed 28 December 2017.

${ }^{139}$ See Uniform Securities Transfer Act (USTA) (2004), Sections 106-116 in conjunction with definitions in Section 1, online: <https://www.ulcc.ca/en/uniform-acts-new-order/current-uniform-acts/761-securities-transfer/2049secbities-transfer-act>, accessed 28 December 2017.

${ }^{140}$ See in general e.g. Benjamin Geva, "Securities Transfers in the Indirect Holding System - Law Reform in Canada in the Footsteps of UCC Article 8" (2007) 18 Journal of Banking and Financial Law and Practice (Australia) 72-77.
} 
envisages a claim premised on an unidentified portion of a mixture of fungible assets (e.g. money) to which ownership passed to the depositary from the various depositors. ${ }^{141}$

Finally, the reader is reminded that historically proposals such as those outlined above preceded the digital age. ${ }^{142}$ Their revival at this point of time can be attributed to the greater ease of implementing them by means of technological innovations that did not exist at the time such proposals were first raised. However, technological feasibility does not necessarily lead to economic justification. For example, as pointed out at the beginning of this section, albeit ahead of Fintech, Goodfriend was on record highlighting the public's substantial efficiency gains of the fractional reserve at the cost of accepted risks, which are anyway mitigated by monetary policy, central bank lending and deposit insurance. ${ }^{143}$ To say the least, under the present system, banks are able to share with customers profit realized from lending out of demand deposits; the chance is that, in a regime under which scriptural central bank money is available to the public in any form, payment services will be more costly. Whether and to what extent gains in safety outweigh efficiency losses may be in the eyes of the beholder. This Section should be taken as outlining banks' continued role and relative advantage in a central bank scriptural money environment rather than necessarily to unequivocally support such a regime.

\section{(iii) Cryptocurrencies and blockchains}

All such innovations, namely the ability to access accounts and transact digitally, the advent of e-money, and the possibility of making central bank money or its equivalent available to the public have not changed the nature of an interbank transfer as a transfer of scriptural money in the form of a balance of monetary value.

A payment instruction and monetary value expressed in encrypted strings of digits are respectively an electronic payment order and electronic money; nonetheless, strictly speaking, they are to be distinguished from digital currencies in which the encrypted string of digits identify a specific monetary item. Indeed, a minority of e-money products may still operate on devices that store electronic "notes" (sometimes called coins or tokens) that are uniquely identified by a serial number and are associated with a fixed, unchangeable denomination. In such a "note-based" model, transactions are performed by transferring notes from one device to another, and the balance of funds stored on a device is thus the sum of the denominations of all notes on the device. However, as in the "balance-based" products, transferability is typically restricted, and consumer cardholders may usually make payments only to merchants who may clear these payments or deposit the accumulated balances exclusively through their acquiring

\footnotetext{
${ }^{141}$ In general, for the irregular deposit, see Robert W Lee, The Elements of Roman Law with a Translation of the Institutes of Justinian, 4th ed (London: Sweet \& Maxwell, 1956) at 295 and R. Zimmermann, The Law of Obligations-Roman Foundations of the Civilian Tradition (Cape Town: Juta, 1990) at 215-19.

142 Particularly for full-reserve banking. See Lainà, supra note 123.

${ }^{143}$ Goodfriend, supra note 10 at 261. Bank regulation could be added to the listed items.
} 
banks. ${ }^{144}$ Arguably however, such a product provides the link between traditional value-transfer systems to innovative circulating digital coins.

The ensuing discussion excludes currencies not linked to the real economy ${ }^{145}$ and is limited to coins that could be liquefied and redeemed, so as to be available for use in real trading, as well as for purchase of goods and services. Payment by such digital coins has the potential of bypassing both the bank account and the centralized multilateral interbank settlement. For its part, a digital coin is "an entity that amounts to a string of bits." The string must have a numerical value and it must have a unique identity, something against which "[c]oins with a definite physical existence are inherently immunized." After all, unlike physical currency which cannot be repaid by the payer once it has been handed over to the payee, "a [spent] digital coin keeps a copy of itself in the hands of the payer," who may thus either mistakenly or fraudulently re-spend it. ${ }^{146}$ Hence, double spending is an issue for all types of digital currency.

The 'series of bits' which constitutes a digital coin can be either 'self-anchored' or in a 'claim-check' (redeemable token) format. ${ }^{147}$ In this respect the distinction is not necessarily between privately issued digital currencies, known as virtual currencies, ${ }^{148}$ and digital currencies issued by central banks (or otherwise by the state), generally known as Central Bank Digital

${ }^{144}$ CPSS, Security of Electronic Money (Basel: BIS, 1996) particularly at 5, online: $<$ https://www.bis.org/cpmi/publ/d18.pdf>, accessed 28 December 2017.

145 Such are:

i) closed/'in-game only' schemes, in which a link to the real economy or fiat currency hardly exists; ii) schemes with unidirectional flow, under which the currency may originally be purchased with a fiat currency but may not be converted back to it, such as Facebook Credits, and even; iii) schemes with a bidirectional flow, envisaging conversion in both directions, albeit usually not used in entirely open loops throughout the entire economy, such as air miles in Frequent Flyer Programs

See European Central Bank/Eurosystem, Virtual Currency Schemes (October 2012) at 12-15, online: $<$ https://www.ecb.europa.eu/pub/pdf/other/virtualcurrencyschemes201210en.pdf>, accessed 12 March 2018. For an explanation as to why such a currency will not "migrate" to the real economy, see, e.g. Joshua S Gans and Hanna Halaburda, supra note 115.

${ }^{146}$ Gideon Samid, Tethered Money: Managing Digital Currency Transactions (London: Academic Press, 2015) at 105-106.

${ }^{147}$ Samid, ibid at 108.

${ }^{148}$ I use 'virtual currencies' in the sense of privately issued digital currencies, as for example under the Regulation of Virtual Currency Businesses Act, online: <http://www.uniformlaws.org/Act.aspx?title=Regulation\%20of\%20Virtual-Currency\%20Businesses\%20Act> accessed 28 December 2017, s.102(23) of which defining "[v]irtual currency" as "a digital representation of value that is used as a medium of exchange, a unit of account, or a store of value; and is not legal tender..." "Legal tender" is defined in s.102(8) as

"the medium of exchange or unit of value, including the coin or paper money of the United States, issued by the United States or by another government." 
Currencies (CBDCs). Nonetheless, a digital currency issued by a central bank may not be selfanchored; rather, it must be a claim-check only in the sense that it entitles its holder to redeem or convert it either to bank money or physical currency in the same amount. Conversely, a virtual currency may be either self-anchored or a claim-check.

Self-anchored digital currencies are mathematical creatures; ${ }^{149}$ they hinge on cryptographic algorithms, each being "a procedure or formula for solving a problem," ${ }^{150}$ not only for protection against hacking but also to control the creation of new units and facilitate payments. Not being anchored to a specific tradeable asset, such as a commodity or a fiat currency, a self-anchored digital currency is inherently unstable, volatile, and easily amenable for speculation. ${ }^{151}$

Conversely, in a claim-check format, a digital coin is a claim against a specified measure of a defined tradeable asset, or a cocktail thereof, such as a commodity or a fiat currency. ${ }^{152}$ Its bit string may be defined by and expressed in sequences of bits which are totally and completely random and pattern-less. ${ }^{153}$ In principle, and of course subject to authorization by law, a digital coin may be issued also by (or on behalf of) the central bank as a claim to its own fiat currency, and not as a self-anchored digital currency. In a properly managed virtual currency issued in a claim-check format, every digital coin should always be backed 1-to-1 by the same value of the underlying asset held in reserves, so as to be available for redemption on demand even when made by all holders at the same time. Reserve reports are to be published daily and frequently audited. ${ }^{154}$

Broadly speaking, 'cryptography' denotes "a method of storing and transmitting data in a particular form so that only those for whom it is intended can read and process it." 155 At the same time, strictly speaking, the term points at a specific method to that end, under which "complexity ... is injected into data so that only those who possess a key ... can remove the complexity ...

\footnotetext{
${ }^{149}$ Samid, supra note 146 at 14.

${ }^{150}$ See definition of 'algorithm' at <http://whatis.techtarget.com/definition/algorithm>, accessed 28 December 2017.

${ }^{151}$ See e.g. Samid, supra note 146 at 14-15 (on the concept of self-anchored money), and 109-110 (on selfanchoring in bitcoins). While by definition, a fiat currency is a mere abstract obligation of a central bank and its value is not anchored in a commodity, the stability of its value hinges on the powers and obligations of the drivers of that economy, which is obviously not the case for self-anchored virtual currency.

${ }^{152}$ Samid, supra note 146 at 22 (on cascaded digital money), 64-65 (on claims to fiat currency), 106 (on centralized digital currencies) and 121 (on fiat digital currency, claim-check format).

${ }^{153}$ For the superior protection of randomness premised on "a cipher which use[s] no mathematical complexity but instead call[s] for large amounts of randomness" see e.g. Carsten Stöcker and Gideon Samid, "Randomness: The Fix for Today’s Broken Security”, online: <https://medium.com/@ cstoecker/randomness-the-fix-for-todays-brokensecurity-39ea7dc3a89b>, accessed 9 January 2018.

${ }^{154}$ See e.g. <www.tether.to>, accessed 28 December 2017. See also Samid, supra note 146 at 125.

${ }^{155}$ See definition of "cryptography" online: <http://searchsoftwarequality.techtarget.com/definition/cryptography>, accessed 28 December 2017.
} 
and understand the intended message, while those without the key will not be able to retrieve the hidden message in a timely manner." The "process of applying cryptography to a message so that only its intended readers can understand it" is called 'encryption'; the reverse, namely the "process of using a ... key to recover the intended message from its encrypted form," is called 'decryption.' Where the sender and receiver of a cryptographic message "share the same key data or mutually deducible key data," encryption is 'symmetric'. Otherwise, where they do not share the same key data, encryption is said to be 'asymmetric'. Cryptographic complexity addresses factors relating to the decryption of the message and its result. ${ }^{156}$ Accordingly, as explained further below, "cryptocurrency" denotes a digital currency in which encryption techniques are used to regulate the generation of units of currency and verify the execution of payment transactions ${ }^{157}$ on a decentralized network.

A fundamental distinction thus exists between centralized and decentralized digital currency schemes. A scheme in which coins are issued and redeemed under a centralized protocol is said to be centralized. At the same time, a digital currency that is issued, transferred, and redeemed over a distributed ledger is decentralized. Finally, a digital currency transferable over a distributed ledger and yet issued by a centralized operator is hybrid. ${ }^{158}$ Regardless, payees may protect themselves against receiving digital coins that are either fake or have already been paid (or 'double spent') by respective payers by consulting an 'oracle' as to their validity. In case of a centralized system, the 'oracle' is the issuer; in a decentralized system, the 'oracle' is the blockchain. ${ }^{159}$

The distributed ledger underlying decentralization is an asset database that can be shared across a network of multiple sites, geographies or institutions. ${ }^{160}$ Blockchain is an underlying technology, requiring the Internet to support and maintain its peer-to-peer network, that enables digital implementation of a distributed ledger. Being a computerized ledger on a distributed network, it generates a single version of the record on each computer and in essence is: ${ }^{161}$

\footnotetext{
${ }^{156}$ For definition of "cryptographic complexity" (as well as “cryptographic equivocation"), see Samid, supra note 146 at $139-40$ (Glossary).

157 This definition slightly modifies the one from https://medium.com/@Wolfofcrypto/basic-cryptocurrency-starterguide-8f2071ea85de; particularly, I replace 'transfer of funds' by the 'execution of payment transactions' to point at payment by the transmission of 'coins' rather than 'generic value' in the forms of funds.

${ }^{158}$ For this tripartite classification, see IMF Staff Discussion, Virtual Currencies and Beyond: Initial Considerations (January 2016) at 8-9, online: <https://www.imf.org/external/pubs/ft/sdn/2016/sdn1603.pdf>, accessed 28 December 2017 (where a third criterion is added viz., "mechanisms to implement and enforce internal rules on the use and circulation of the currency").
}

\footnotetext{
${ }^{159}$ Samid, supra note 146 at 92-94 (on the oracle's role), 106 (an illustration of this role), and 126 (oracle's role addressing secondary risks).
}

${ }^{160}$ UK Government Office for Science, "Distributed Ledger Technology: beyond block chain" (2016) at 17-18, online: <https://www.gov.uk/government/uploads/system/uploads/attachment_data/file/492972/gs-16-1-distributedledger-technology.pdf $>$, accessed 28 December 2017.

${ }^{161}$ UK Government Office for Science, Ibid at 17. See also e.g. CPMI, Distributed ledger technology in payment, clearing and settlement system - An analytical framework (Basel: BIS, February 2017), online: 
a type of a database that takes a number of records and puts them in a block ... Each block is then 'chained' to the next block, using a cryptographic signature. This allows block chains to be used like a ledger, which can be shared and corroborated by anyone with the appropriate permissions.

Accuracy of the ledger is corroborated under a method determined under rules adhered by participants. Record security and visibility to authorized users is ensured by cryptography.

Cryptography is thus used in cryptocurrencies to express and protect the value of the coins (the sequence of the bits), to prevent counterfeiting and fraudulent transactions, as well as to perform the validation and execution of transactions records via a distributed ledger, such as the blockchain. As explained below, each block contains a cryptographic hash or algorithm that links it to the previous block along with a timestamp for the transactions from that block. The network allows online payments to be sent directly from one party to another without going through a bank or any other centralized counterparty. ${ }^{162}$

The pioneering digital cash scheme, and the most prominent one so far, is Bitcoin. ${ }^{163}$ It is a virtual, self-anchored cryptocurrency and a peer-to-peer decentralized system. ${ }^{164}$ In his seminal paper, ${ }^{165}$ its mythological founder Satoshi Nakamoto defined Bitcoin as an "electronic coin" consisting of a "chain of digital signatures" transferable from the payer to the payee "by digitally signing a hash of the previous transaction and the public key of the next owner and adding them

<http://www.bis.org/cpmi/publ/d157.pdf $\geq$, accessed 28 December 2017; and David Mills, Kathy Wang et al., "Distributed ledger technology in payments, clearing and settlement" (2016) Federal Reserve Board Division of Research \& Statistics and Monetary Affairs Finance and Economics Discussion Series 2016-095, online: <https://www.federalreserve.gov/econresdata/feds/2016/files/2016095pap.pdf>, accessed 28 December 2017.

${ }^{162}$ See e.g. Lam Pak Nian and David Lee Kuo Chuen, "Introduction to Bitcoin" in David Lee Kuo Chuen, ed, Handbook of Digital Currency: Bitcoin, Innovation, Financial Instruments and Big Data, (Amsterdam etc. Elsvier, 2015), at 5 and 8 .

${ }^{163}$ In the broader context of subsequent "plenty of alternatives" see e.g. Andreas Hanl, "Some Insights into the Development of Cryptocurrencies" (2018) MAGKS Joint Discussion Paper Series in Economics No 04-2018, online: <https://www.uni-marburg.de/fb02/makro/forschung/magkspapers/paper_2018/04-2018_hanl.pdf>, accessed 12 March 2018.

164 See e.g. Stuart Hoegner, "What is Bitcoin?" in Stuart Hoegner, ed, The Law of Bitcoin (Bloomington IN: iUniverse, 2015) at 1; Neil Guthrie, "The End of Cash? Bitcoin, the Regulators and the Courts" (2014) 29 BFLR 355. For its mechanics, see Jonathan Levin, "Bitcoin: New Plumbing for Financial Services", coindesk (29 November 2014), online: <http://www.coindesk.com/bitcoin-new-plumbing-financial-services/>, accessed 28 December 2017. See also Nicholas Wenker, "Online Currencies, Real-World Chaos: The Struggle to Regulate the Rise of Bitcoin" (2015) 19 Tex Rev L \& Pol 145; and Jacob Hamburger, "Bitcoins vs. State Money Transmission Laws: Protecting Consumers or Hindering Innovation?" (2015) 11 J L Econ \& Pol'y 229. See also:

$<$ https://en.wikipedia.org/wiki/Bitcoin>, accessed 28 December 2017; <http://www.coindesk.com/information/whatis-bitcoin/ $\geq$, accessed 28 December 2017; http://www.wired.com/2011/11/mf_bitcoin/, accessed 28 December 2017; and "The Great Chain of Being Sure About Things", The Economist (31 October 2015). See also European Central Bank/Eurosystem, supra note 145 at 21-24 and <https://en.bitcoin.it/wiki/How_bitcoin_works>, accessed 28 December 2017.

${ }^{165}$ Satoshi Nakamoto, "Bitcoin: A Peer-to-Peer Electronic Cash System" (2008) at 2, online: $<$ https://bitcoin.org/bitcoin.pdf>, accessed 28 December 2017. 
to the end of the coin.". Premised on distributed ledger technology (DLT), Bitcoin was born out of an ambition to create government-independent, censorship-resistant money.

Bitcoin payments are carried out over the Bitcoin network through 'asymmetric', cryptography. ${ }^{166}$ Each participant is assigned a pair of keys: one private that is to be kept by the participant confidential, and one public to be made known to potential counterparties. To initiate payment, the payee sends the payer the payee's public key. Using the payee's public key together with data relating to the previous transaction to create a message, the payer's software will 'hash', namely crunch down the message data into a few lines, and encrypt it with the payer's own private key, thereby digitally signing it. A hash function irreversibly maps a variable length message to data of a fixed-size bit string length, called a 'hash', 'hash value' or 'digest.' 167

To carry out payment, the payer submits the transaction to its local node, which checks, among other things, that the payer has the bitcoins the payer now wants to spend. The local node provides a go-ahead for the transaction processing and broadcasts it to other nodes through the entire distributed network. All payments are sent to the network and are public, except that no information is given as to the identity of the parties, other than the wallets involved. Payments are 'time-stamped' so as to ensure that data will be neither altered nor reused, thereby eliminating double spending. ${ }^{168}$ In a way, this is an accounting scheme, using crypto principles rather than plain identification of digital coins.

Each node is operated by a 'miner'. Miners then bundle the proposed payment with others and create a new block for the blockchain. The new block is hashed and, together with other data, is rehashed. The data is repeatedly fed through a cryptographic 'hash' function. The hash is put into the header of the proposed block and becomes the basis for a mathematical puzzle. The 'miners' compete to reach a solution for it, and the first to come up with the right solution, as accepted by the majority of miners who submitted 'proof of work', ${ }^{169}$ is rewarded

\footnotetext{
${ }^{166}$ See information on 'public key cryptography' at e.g. <https://en.wikipedia.org/wiki/Public-key_cryptography>, accessed 28 December 2017.

167 "Hashing" was defined to be "a cryptographic technique to generate a unique code to represent [a] document which keeps the contents of that document confidential [so as] to verify that [it] exists and has not been tampered with." See: "Discussion Paper on distributed ledger technology" Financial Conduct Authority Discussion Paper DP 17/3 at 18, online: <https://www.fca.org.uk/publication/discussion/dp17-03.pdf>, accessed 28 December 2017.
}

${ }^{168}$ However, as long as the transaction information does not reach the blockchain, under some conditions, it may be fraudulently intercepted by the receiver who is then able to make minor changes to the peripheral information that will generate a new transaction ID but not invalidate the transaction, while allowing the receiver to keep seeking payment from the sender who is unable to track the transaction due to its mutation. This is the risk of transaction malleability, particularly incurred for bitcoins held with an intermediary. Attackers used Bitcoin transaction malleability to endlessly request bitcoins from their accounts held with intermediaries, eventually draining all of the bitcoins from these targets. See e.g. <https:/www.deepdotweb.com/2014/08/21/bitcoin-transaction-malleabilitytheory-behind-happened-silkroad-2-0-mt-gox/>, accessed 28 December 2017 as well as <http://www.coindesk.com/bitcoin-bug-guide-transaction-malleability/>, accessed 28 December 2017.

169 'Proof of Work' is defined to require "that the decentralized participants that validate blocks show that they have invested significant computing power in doing so." See Fintechblue, "What is Proof of Work?" fintechblue, online: 
with newly 'minted' bitcoins. The mathematical puzzle is hard to solve, but once found, it is easy for the network to confirm that the answer is correct. Nodes accept the block, whose header contains the hash of the previous block's header, by adding it to the chain that stretches back to the first Bitcoin block (the genesis block), containing the first transaction in the Bitcoin network. This construction is designed to make the Bitcoin blockchain tamperproof: if one tries to fake a transaction by changing a block that had already been stored in the blockchain that block's hash would be different and ought to be apparent to all as having been tampered with. The 'coin' thus carries with it its entire history so that each payment becomes part of its code.

Payments are made from one Bitcoin wallet to another. Each such wallet is a computer file or a software program which has an email address. The wallet stores both the private key (in effect the passcode) and the bitcoin ${ }^{170}$ balance controlled by it. What is transferred is 'monetary fluid' representing the bitcoin sum accessed from the payer's wallet and originating from all Bitcoin 'coins' accessed from that wallet. ${ }^{171}$ Stated otherwise, a payer is unable to designate and set aside for payment any particular bitcoin. In effect, payment can be made in any sum available from the wallet, and regardless, at the end of the process, new bitcoins become associated with the payee's wallet, while those still associated with the payer's wallet may have changed their value and hence their identity. Transaction output is thus said to differ from transaction input, if only due to the diversified chain of provenance of input (from the payer's wallet). It would have been more accurate to speak of a Bitcoin payment resulting in a 'coin' being transformed rather than transferred, except that each resulting 'coin' carries with it identities of its predecessors as well as the impact of its subsequent partial use. Transaction information is stored on the blockchain; strictly speaking, the 'coins' themselves are not discrete things and are thus not stored anywhere. As a string of bits they however exist in the wallet so that to access them one needs both the password and control over the physical device or cloud having the wallet. If the device is lost, the use of the bitcoins remains available to the owner only where the wallet has been backed up (and the one in the device possession as well as with knowledge of the passcode has not spent them). ${ }^{172}$

Developing laws to meet DLT in general and Bitcoin in particular is quite challenging. ${ }^{173}$ Legal rules applicable to a DLT can be divided into those dealing with governance and those dealing

<http://www.fintechblue.com/2016/06/what-is-proof-of-work/>, 28 December 2017. According to Satoshi Nakamoto, supra note 165, "[p]roof-of-work is essentially one-CPU-one-vote," rather than "one-IP address-onevote".

${ }^{170}$ Conventionally, "Bitcoin" (capitalized) refers to the technology and network whereas "bitcoins" (lowercase) refers to the currency, units and 'coins'.

${ }^{171}$ A participant may have indefinite numbers of such wallets. In any event, note that what is described in the text is the direct holding of bitcoins. Alternatively, in an indirect holding system, a participant keeps bitcoins with an intermediary. See Ryan J Straus and Matthew J Cleary, "The United States” in Hoegner, ed, supra note 164.

${ }^{172}$ For Bitcoin mechanics, see Levin, supra note 164. For more technical information see e.g. <https://bitcoin.stackexchange.com/questions/39101/what-happens-to-bitcoin-wallet-bitcoins-if-pc-is-stolen>; $<$ https://bitcoin.stackexchange.com/questions/1600/where-are-the-users-bitcoins-actually-stored>; and $<$ https://bitcoin.stackexchange.com/questions/1600/where-are-the-users-bitcoins-actually-stored>, all accessed 9 January 2018. 
with regulation. Governance is rule-making by the owners or participants with a view of safeguarding their own interests. Regulation is rule-making, typically by an outside authority, with the view of representing the public interest. By consent, however, regulation may take place by means of contract or any other consensual organisational mechanism, in which case the line between governance and regulation may be blurred.

Existing legal rules governing payment clearing and settlement have been drafted to accommodate the existing architecture of the system, and hence require adaptation to cover a DLT arrangement. By itself, this is a costly operation. The challenge, however, is to distinguish between those costs that once incurred will lead to a positive change and savings, and those that are effectively inherent in what will amount to a bad substitute to the traditional system. Moreover, in relation to a virtual currency of self-anchored value ${ }^{174}$ payable over a blockchain, such as Bitcoin, a preliminary legal question arises as to whether it is even 'money' in terms of being lawfully usable to discharge a debt, as well as to meet statutory requirements addressing 'money'. Taking into account the fluctuating value of a self-anchored currency, an additional challenge is how to provide for a legal framework facilitating price stability, e.g. by rebasing the amount of money, that is, adjusting the number of cryptocurrency units in every digital wallet. ${ }^{175}$

The decentralized basis of a DLT provides a challenge to governance, particularly in a 'permissionless' DLT arrangement (where the ledger is ownerless). It is a misconception to think of such arrangements as existing independent of human rule-making. This is so because technical rules must be produced and maintained. Unforeseen circumstances are unavoidable, and the power of core developers may be in conflict with the will of the community. For 'permissioned' DLT arrangements (which there is an owner for the ledger), ${ }^{176}$ governance is simpler because by definition there is a proprietor. Compared with both permissioned DLT arrangements as well as traditional payment systems, governance costs in permissionless DLT arrangements are bound to be higher because of the greater complexity of the technical arrangement, the sheer greater number of participants directly involved and the difficulty of getting a timely agreement. This can be seen from the drawn-out process and uncertainty in terms of responsibility and 'chain of command' involved in occurrences such as:

\footnotetext{
173 See: Neyer and Geva, supra note 8. See also UK Government Office for Science, supra note 160; David Miles, Kathy Wang et al., supra note 161; and CPMI, supra note 161.

174 That is, a privately issued digital currency hinging on cryptographic algorithms to control the creation of new units and facilitate payments whose value is not anchored in a specific asset such as a commodity or a fiat currency. See Benjamin Geva, "Disintermediating electronic payments: digital and virtual currencies" (2016) 31:12 Journal of International Banking Law and Regulation at 661 and particularly 667.

${ }^{175}$ See Ferdinando M Ametrano, "Hayek money: the cryptocurrency price stability solution" (2016), online: <http://dx.doi.org/10.2139/ssrn.2425270>, accessed 28 December 2017.

${ }^{176}$ For the definitions for 'permissioned' and 'permissionless' ledgers and a more detailed explanation see e.g. UK Government Office for Science, supra note 160 at 17.
} 
- scaling the size of the blocks in Bitcoin (so as to alleviate the fear that a backlog of transactions awaiting inclusion in future blocks will clog up the Bitcoin network should blocks become consistently full); ${ }^{177}$

- the delays in addressing the known issues in Ethereum that led to the DAO exploit (under which a hacker exploited the design of the DAO and appropriated more or less US\$50m worth of ether); ${ }^{178}$ and

- the Ethereum flash crash (in which the value of the currency crashed within seconds from $\sim$ US\$320 to as low as US\$0.10 as a result of someone placing a multi-million-dollar sell order at market price). ${ }^{179}$

Regulatory legal considerations are numerous:

- There is a legal need to provide for the reliability and authoritativeness of the records on the distributed ledgers.

- Property rights in digital tokens representing physical assets as well as the liabilities and rights of parties transacting over them must be clearly defined and elaborated by law. As things stand now, there is not even a standard satisfactory definition as to what constitutes a digital asset, not to mention an elaboration of its relationship to the physical asset it represents.

- As new mechanisms (such as smart contracts) are created and adopted in payment and clearing systems, a satisfactory legal framework must be established to govern them at an equally rapid pace.

- A DLT arrangement generates new services and hence involves new players as intermediaries or otherwise providers of such services. This means licensing schemes, and possibly market conduct rules, including those applicable to Initial Coin Offerings, must be devised with a view to achieving, maintaining and improving both financial stability and protection of the public.

- To date, such arrangements have mirrored the existing structures - e.g. a Bitcoin Automated teller machine (ATM) parallels traditional ones, etc. However, it has not been validated that (or which) existing laws and rules apply, as is evident from the various treatments of virtual currencies - as property by the US Internal Revenue Service, a commodity by the US Commodity Futures Trading Commission, and as a currency (for VAT purposes) by the European Court of Justice.

- Settlement finality issues must be satisfactorily resolved. Settlement finality was defined to mean "the legally defined moment at which the transfer of an asset or financial instrument, or the discharge of an obligation is irrevocable and unconditional and not susceptible to being unwound

\footnotetext{
${ }^{177}$ See <http://www.coindesk.com/what-is-the-Bitcoin-block-size-debate-and-why-does-it-matter/>, accessed 28 December 2017.

${ }^{178}$ See <https://medium.com/@ MyPaoG/explaining-the-dao-exploit-for-beginners-in-solidity-80ee84f0d470>, accessed 28 December 2017, as well as <https://www.bloomberg.com/features/2017-the-ether-thief/>, accessed 28 December 2017.

${ }^{179}$ See https://medium.com/@ MyPaoG/explaining-the-dao-exploit-for-beginners-in-solidity-80ee84f0d470, accessed 28 December 2017, as well as <https://www.bloomberg.com/features/2017-the-ether-thief/>, accessed 28 December 2017.
} 
following the bankruptcy or insolvency of a participant" ${ }^{180}$ It is essential for the efficient operation of a payment clearing and settlement system. Indeed, blockchain systems are designed to prevent the 'double spending' of a 'coin' so as to ensure that payment will be carried out only with available funds. In a DLT arrangement, however, the process of settlement may not be short or even of an exact or predictable duration, and the point of finality may not be easily identifiable. In the proof-of-work model, the first updating instance merely signals the beginning of the process of ledger synchronisation leading to the achievement of consensus across the nodes. Hence, subsequent models (consensus, proof of stake) are being examined to address the technical considerations of, for example, defined service-level agreements to achieve final consensus.

- More complexity is introduced via Delivery vs. Payment (DVP) or Payment vs. Payment (PVP) systems. Furthermore, a DLT arrangement legal framework may neither provide for nor even address legal settlement finality. Indeed, settlement issues become even more complex when assets off the chain or off-chain transactions are considered.

- The payment systems must comply with secrecy, anti-money laundering and anti-terrorist financing requirements. All of these are costlier in the distributed (no governing jurisdiction) and permissionless (no identifiable responsible party) environments. In fact, decentralization further challenges traditional methods of the enforcement of a judgment as well as of a security interest as, without the cooperation of the owner of an asset placed on the blockchain, the asset may not be accessible.

- Certain issues existing in relation to electronic funds transfers appear in a modified form in payment over a blockchain, such as mistaken as well as unauthorized payments. Particularly acute is the loss of hardware or password resulting in loss of money or monetary value. Unlike in a traditional payment system, there is no funds holder intermediating in the payment transaction, or in fact any accountable intermediary involved in the process of payment, which could potentially absorb losses and distribute the costs or assist in the recovery of losses.

- Last and certainly not least, numerous questions arise regarding 'conflict of laws'. Such questions relate to jurisdiction as well as to the selection of law that will apply to private arrangements. This is particularly notable in light of the inherent ambiguities in pointing at the location of a contract/transaction, the blockchain and the money or monetary value itself.

Regulatory arrangements are partly set by the authorities and partly by contract or otherwise by autonomous industry bodies. Contractual or other private arrangements require negotiations and agreement — activities in which costs are incurred. Compliance with regulatory arrangements, of whatever source, is costly. Intuitively, the mere decentralised nature of the blockchain arrangement, not to speak of its novelty as outlined above, is likely to increase compliance costs. Novelty and lack of precedents are certain sources of higher dispute resolution costs including litigation costs. ${ }^{181}$

Globalization is enhanced by the cross-border scope of DLT in general and blockchain technology in particular. At the same time, law-making has not caught up with globalization. As such, there is a good chance that jurisdiction-by-jurisdiction law-making will be neither uniform nor even harmonious. The segmentation will increase disputes involving conflict of laws, as outlined above; therefore it is also bound to increase regulatory compliance costs. To meet the needs arising in such an

\footnotetext{
${ }^{180}$ CPMI, supra note 161.

${ }^{181}$ For one type of dispute see e.g. <http://www.coindesk.com/Bitcoin-mining-fraud-lawsuit-moves-forward-newjersey/>, accessed 28 December 2017.
} 
environment, regulatory technology (RegTech) solutions are being offered with claims to achieving significant reduction in costs. ${ }^{182}$ It may be too early to assess and quantify the value generated by such solutions.

At present, any claim to legal cost reduction in a blockchain environment remains unproven. Moreover, it seems that RegTech solutions will work equally well for traditional payment systems, so that any alleged competitive advantage they give to blockchain technological solutions remains tenuous. In the final analysis, legal costs will not be the dominant factor for blockchain technological solutions for payment and settlement systems. Issues raised in the course of globalisation, such as segmented regulation, also exist for traditional payment systems, and in each case are to be met by greater harmonization of the law-making process. In the final analysis, once and wherever a strong business case is made for the adoption of blockchain technological solutions, the chance is that legal requirements designed to make adoption possible will be worked out whatever their cost may be. The burden of legal costs may make a difference only in solutions with a marginal business case that do not have the margin to absorb even small variations.

It is argued that developers of cryptocurrencies "simply migrated the cryptographic tools used to safeguard communication and applied them to safeguard digital currency". ${ }^{183}$ Hence the vulnerability to erosive cryptographic intractability from which Bitcoin suffers, in addition to its vulnerability to leadership corruption. ${ }^{184}$ Also, its operation, whether in facilitating payments, preventing double spending, or issuing new bitcoins, requires substantial computational energy and is thus said to be wasteful. ${ }^{185}$ Bitcoin also suffers from poor scalability, as it can handle at most 7 transactions per second, ${ }^{186}$ compared to Visa and Mastercard that clear in a second 2,000

\footnotetext{
${ }^{182}$ See < https://bitcoinmagazine.com/articles/regtech-fintech-may-be-next-big-thing-bitcoin-and-blockchainspace/>, accessed 28 December 2017, as well as http://www.prweb.com/releases/2017/04/prweb14269864.html>, accessed 28 December 2017.

${ }^{183}$ Samid, supra note 144 at 26. See also Samid, ibid at 101 for an argument against extrapolating cryptotools for transient communication to shielding digital currency.

${ }^{184}$ For details on the main bitcoin principles, see Samid, ibid at 108-116.

${ }^{185}$ See details at e.g. Christopher Malmo, "Bitcoin is Unsustainable", Vice: Motherboard (29 June 2015), online: <http://motherboard.vice.com/read/bitcoin-is-unsustainable>, accessed 28 December 2017; See also e.g. John Quiggin, "Bitcoins are a waste of energy-literally", ABC News (5 October 2015), online:

<http://www.abc.net.au/news/2015-10-06/quiggin-bitcoins-are-a-waste-of-energy/6827940>, accessed 28 December 2017.

${ }^{186}$ See e.g.

$<$ https://en.bitcoin.it/wiki/Scalability_FAQ\#What_is_this_Transactions_Per_Second_.28TPS.29_limit.3F>, accessed 28 December 2017.
} 
transactions, ${ }^{187}$ or even a peak-volume of 10,000 transactions per second. ${ }^{188}$

Certainly, however, Bitcoin is driven not only by technological innovation but also by strong sentiments ${ }^{189}$ against currency systems based on bank credit ${ }^{190}$ and backed by government. ${ }^{191}$ Its promoters cite its non-inflationary basis, ${ }^{192}$ partly attributed to the limitation on the number of bitcoins to be generated by its protocol; yet they overlook that, in the long run, the finite number of bitcoins in existence may prove to adversely affect both prices and liquidity ${ }^{193}$, not to mention that the current 21 million cap is not engraved in stone and is thus subject to change. ${ }^{194}$ Nevertheless, in the final analysis, Bitcoin's principal weakness lies in the inherent instability in its value, ${ }^{195}$ due to its being a self-anchored digital currency. In the absence of any "objective rational[e] for any exchange value" Bitcoin is thus likened to "a game that triggered universal interest ... [but whose] infirmity is as intrinsic as Monopoly money." Furthermore, a competitor's self-anchored math-based currency may emerge and thereby lower the Bitcoin value. This casts a shadow on the acceptability of Bitcoin as a real substitute to fiat currency. ${ }^{196}$ It has specifically been suggested that, to meet this drawback, Bitcoin should be pegged in one way or another to the value of a specific fiat currency or commodity, ${ }^{197}$ albeit at a heavy ideological cost to its promoters, who prefer to highlight its lack of dependence on anything of that sort.

\footnotetext{
${ }^{187}$ Saifedean Ammous, "Blockchain Technology: What is it good for?" (8 August 2016) at 2, online: $<$ https://poseidon01.ssrn.com/delivery.php?ID=6970011271260741151271140771230800741030240360440860031 000751011251240800231240890291100320530221090490031200080680960980701151160830940220861200681 031221250251130980050650670200931231181110290040710920170230921210000250640041121230790761140 $65120009100 \& E X T=$ pdf $>$, accessed 28 December 2017.

${ }^{188}$ Timothy B Lee, "Bitcoin needs to scale by a factor of 1000 to compete with visa. Here's how to do it.", The Washington Post (17 November 2005), online: <https://www.washingtonpost.com/news/theswitch/wp/2013/11/12/bitcoin-needs-to-scale-by-a-factor-of-1000-to-compete-with-visa-heres-how-to-doit/?utm_term=.f6e09d78860d>, accessed 28 December 2017.

${ }^{189}$ For an overview, citing the sources as immediately below, see European Central Bank/Eurosystem, supra note Fehler! Textmarke nicht definiert. at 22-23.
}

${ }^{190}$ Murray N Rothbard, Economic Depressions: Their Cause and Cure (Alabama: Ludwig von Mises Institute, 2009).

${ }^{191}$ Friedrich A Hayek, Denationalisation of Money, 3rd ed (London: The Institute for Economic Affairs, 1976).

${ }^{192}$ European Central Bank/Eurosystem, supra note 189.

${ }^{193}$ Samid, supra note Fehler! Textmarke nicht definiert. at 113.

${ }^{194}$ Hoegner, ed, supra note 164 at 1, 9 n. 57.

${ }^{195}$ For a discussion on the nature of Bitcoin value, see e.g. William J. Luther, "Is Bitcoin Intrinsically Worthless?" (July 2017), online: https://papers.ssrn.com/sol3/papers.cfm?abstract_id=3000068, accessed 28 December 2017.

${ }^{196}$ Samid, supra note 146 at 14-15 (for an illustration of instability), and 109-110 (for connection between selfanchoring and instability). The quotation is from p. 15.

${ }^{197}$ Samid, ibid at 114-121. 
Decentralization and the resulting absence of a trusted central counterparty may however be more of a curse than a blessing. ${ }^{198}$ According to Saifeadean Ammous, inefficiency is inherent in the blockchain technology in general and Bitcoin in particular: ${ }^{199}$

Bitcoin has a blockchain not because it allows for faster cheaper transactions, but because it removes the need to trust in third party intermediation: transactions are cleared because nodes compete to verify them, yet no node needs to be trusted. It is unworkable for third party intermediaries to imagine they could improve their performance by employing a technology that sacrifices efficiency and speed precisely to remove third party intermediaries. For any currency controlled by a central party, it will always be more efficient to record transactions centrally. Whether removing third party intermediation is a strong enough advantage to justify the increased inefficiency of distributed ledgers is a question that can only be answered over the coming years in the test of market acceptance of digital currencies. What can be clearly seen is that blockchain payment applications will have to be with the blockchain's own decentralized currency, and not with centrally-controlled currencies.

Elsewhere Ammous explains that it is the high processing power threshold which prevents both hacking and the establishment of a central control. Both achievements secure neutrality and full benefit of decentral structure for Bitcoin, and yet at the cost of a fixed supply of growth that cannot be made to adjust to satisfy a purely market-determined demand and hence results in price instability. At the same time, he observes, attempts in other currencies to bypass the expensive, inefficient and wasteful Proof of Work (PoW), by other settlement mechanisms such as Proof of Stake, ${ }^{200}$ consensus, or a trusted notary, compromise the neutrality of the system, enhance the control of the issuer, and/or require a third party verificator, all at the expense of the DLT premises. Hence, he concludes, Bitcoin could be no more than a store of value ${ }^{201}$ while other cryptocurrencies cannot fulfill any monetary feature. ${ }^{202}$

\footnotetext{
${ }^{198}$ For an interesting historical study on the lessons from the misfortune of such absence see eg. Isabel Schnabel and Hyun Song Shin, Money and trust: lessons from the 1620 for money in the digital age (Basel: BIS, February 2018) online: <https://www.bis.org/publ/work698.pdf>, accessed 12 March 2018.

${ }^{199}$ Ammous, supra note 187 at 2.

${ }^{200}$ For the difference between proof of work and proof of stake see e.g.: https://www.google.ca/search?rls=com.microsoft:en-

CA:IEAddress\&dcr=0\&q=what+is+the+difference+between+proof+of+work+and+proof+of+stake? \&spell=1\&sa= X\&ved=0ahUKEwj38Knl1azYAhUm94MKHekWAF8QvwUIJigA\&biw=1094\&bih=625>, accessed 28 December 2017.
}

${ }^{201}$ Not everybody is in agreement. For considering Bitcoin to be an "imperfect store of value" due to its volatility see Aaron Kumar and Christie Smith, "Crypto-currencies - An introduction to not-so-funny moneys" (November 2017) Reserve Bank of New Zealand Analytical Note Series, AN2017/07 at 2, online: <https://www.rbnz.govt.nz//media/ReserveBank/Files/Publications/Analytical\%20notes/2017/an2017-07.pdf>, accessed 9 January 2018.

\footnotetext{
${ }^{202}$ Saifedean Ammous, "Can cryptocurrencies fulfill the functions of money?" (August 2016), online: <https://poseidon01.ssrn.com/delivery.php?ID=89803106806902001308410009400111511302400804906803>, accessed 28 December 2017.
} 
The technology developed by Ripple is an example for both the price of abandoning PoW as well the lack of monetary feature of its currency. Thus, in Ripple, non-correspondent payer's and payee's banks can settle a payment made in a fiat currency. They use distributed financial technology to replace a trusted third bank and settle with each other through a 'connector', the latter being any entity that has accounts on the books of both. The two banks use distributed financial technology to coordinate account entries involving the connector's accounts on each of their own respective books. Specifically, the payer's bank would increase the balance it owes to the connector and, at the same time, the payee's bank would decrease the balance it owes to the connector. The two banks would use distributed financial technology to communicate, coordinate, validate, and record their credit and debit to the connector's accounts. ${ }^{203}$ Effectively, while weaving all participants into a comprehensive network rather than tying their distinct systems, Ripple has nevertheless not removed intermediation; in addition to reliance on connectors, the operation of the transfer thereunder is premised on a distributed ledger maintained by Ripple Lab, whose operation is not premised on PoW calculations. For its part, Ripple's own native currency XRP is issued from a distributed protocol and yet unlike Bitcoin, is "pre-minted"; ${ }^{204}$ it is centrally controlled and while it can be used in international payments ${ }^{205}$ it may be "better understood as a token for using the Ripple network, not as a currency of its own right" 206

Ammous does not see the deflationary nature of Bitcoin as an impediment to its unit of account function. At the same time, having highlighted Bitcoin's inadequacy to serve as a medium of exchange for everyday transactions, he argues in a forthcoming book that Bitcoin may be "the best store of value humanity ever invented" so as to be capable of functioning as "a reserve currency" to be held by banks in cold storage. ${ }^{207}$ Against it they will perform payment transactions by debiting payers' accounts and crediting those of payees. With it they will settle. Other than eliminating the central bank, this model will mimic the role of banks in relation to

\footnotetext{
${ }^{203}$ For a detailed analysis, including the application of Article 4A of the Uniform Commercial Code in the US to the settlement over the Ripple system, see Jessie Cheng and Benjamin Geva, "Understanding Block Chain and Distributed Financial Technology: New Rails for Payments and an Analysis of Article 4A of the UCC", Business Law Today 25 no. 7 (March 2016), online: http://www.americanbar.org/publications/blt/2016/03/05_cheng.html, accessed 28 December 2017.
}

${ }^{204}$ See e.g. <https://ripple.com/build/reaching-consensus-ripple/>, accessed 12 March 2018. A detailed description of Ripple consensus process is available at: < https://ripple.com/build/xrp-ledger-consensus-process/>, accessed 12 March 2018.

${ }^{205}$ See e.g. Jessie Cheng, "Blockchain-Based Innovation in Cross-Border Payments: Public Policy Opportunities and Regulatory Challenges" (2018) 2:1 The Current: The Journal of PLI Press 41.

${ }^{206}$ See Ammous, supra note 202.

${ }^{207}$ Saifedean Ammous, The Bitcoin Standard: The Decentralized Alternative to Central Banking Chapter 9 [forthcoming] (from which both cites are taken) as well as Chapter 10. For an ad see eg. $<$ https://www.amazon.com/Bitcoin-Standard-Decentralized-Alternative-Central/dp/1119473861?tag=uuid00-20>, accessed 28 December 2017. For predicting that Bitcoin will achieve gold parity so as to cause in gold value to decrease see e.g. Katrik Hegadekatti, "Blockchain Technology - An instrument of Economic Evolution?" (2017) MPRA Paper No 82852, online: online: <https://mpra.ub.uni-muenchen.de/82852/1/MPRA_paper_82852.pdf>, accessed 12 March 2018. 
payments in fiat currencies so that everyday Bitcoin transactions will be carried out 'off-chain' in effect through banks or similar deposit taking institutions. In any event, the system envisaged by Ammous eliminates the central bank and its role as a lender of last resort as well more in general in relation to monetary policy. This is not the place to discuss the merits and demerits of such a proposed system. For our purposes suffice it to predict that in the current environment it will be a hard sell to policy makers, politicians, and the public at large. ${ }^{208}$

A few central bank cryptocurrency schemes have been floating. ${ }^{209}$ In the US, proposals have been made for Fedcoin, being a central bank-issued centrally created cryptocurrency, to be available to the public at large. ${ }^{210}$ Digital coins are to be centrally issued on a blockchain-style decentralized ledger, but nevertheless with the central bank being in full control of quantity, timing, and fixed value in denominations of the national fiat currency unit of account. Effectively, transactions will be validated by an independent notary nominated by the central bank. So far as I know no detailed scheme has been flashed out. A similar proposal was made in the UK for RSCoin. ${ }^{211}$ Another proposal is for a NationCoin, being a Regulated and Sovereign Backed Cryptocurrency (RSBC). The scheme envisages cryptocoins, which as in Bitcoin, will be created by and transacted over a blockchain. However, upon their creation, cryptocoins will be stored, and released to the public by a Digital Asset Reserve, as RSBC, at the fixed value of the national unit of account. Transactions are to be verified by 'miners' who will be paid freshly minted cryptocoins. ${ }^{212}$

In assessing such proposals, I have still to be persuaded that a DLT settlement is superior to a centralized one as discussed in the ensuing Section for claim-check centralized digital

\footnotetext{
${ }^{208}$ For a more moderate hypothetical variation, under which currency issued under the Bitcoin standard will consist of Bitcoin, as well as fiduciary currencies issued by central banks and commercial bank money, both backed by Bitcoin, and in which central banks will continue to be lenders of last resort, see Warren E Weber, "A Bitcoin Standard: Lessons from the Gold Standard" (2016) Bank of Canada, Staff Working Paper 2016-14, online: <https://www.bankofcanada.ca/wp-content/uploads/2016/03/swp2016-14.pdf>, accessed 9 January 2018.
}

${ }^{209}$ See: Morten Bech and Rodney Garratt, "Central bank cryptocurrencies” (2017) BIS Quarterly Review, at 55, online: <https://www.bis.org/publ/qtrpdf/r_qt1709f.pdf>, accessed 12 March 2018. See also: Katrik Hegadekatti, "Towards Regional Monetary Unions through Blockchain Networks" (2017) MPRA paper No 82838, online: $<$ https://mpra.ub.uni-muenchen.de/82838/>, accessed 12 March 2018; and Heike Mai, "Why would we use crypto euros? Central bank-issued digital cash - a user perspective" (2018) EU Monitor Global financial markets, online: <https://www.dbresearch.com/PROD/RPS_EN-PROD/PROD0000000000462095.PDF>, accessed 12 March 2018.

${ }^{210}$ See e.g. Wendy McElroy, "Fedcoin: The U.S. Will Issue E-Currency That You Will Use”, Bitcoin.com (12 January 2005), online: <https://news.bitcoin.com/fedcoin-u-s-issue-e-c, urrency/>, accessed 28 December 2017.

${ }^{211}$ See George Danezis and Sarah Meiklejohn, Centrally Banked Cryptocurrencies (London: University College London, 2015), online: <https://eprint.iacr.org/2015/502.pdf>, accessed 28 December 2017. In part this article is too technical to the uninitiated in computer science and related subjects (including myself). "RSCoin is the core of a system of scalable and auditable transactions, not a full product" which thus could be used as a basis for either a retail or wholesale product. Email message to the author from George Danezis dated 4 December 2017.

${ }^{212}$ Kartik Hegadekatti and Yatish S G, "Generation, Security and Distribution of MationCoins by a Sovereign Authority" (7 Jan 2017), online: <https://papers.ssrn.com/sol3/papers.cfm?abstract_id=2888347>, accessed 28 December 2017. 
currencies.

Even as NationCoin envisages access for the public at large, its decentralized ledger is classified as permissioned. At the same time, with respect to the blockchain, neither different considerations apply, nor other results emerge, upon moving away from unpermissoned ledgers, open to the public, such as Bitcoin, to a permissioned one, open only to a selected group. ${ }^{213}$ This is demonstrated by the experimentation as a proof of concept (PoC) in Canada under the Jasper Project $^{214}$ as well as in Singapore under the Ubin Project. ${ }^{215}$

By definition, a central bank digital currency ought to be issued centrally, even if payments in it are to be settled de-centrally; in short, a central bank cryptocurrency must be hybrid. ${ }^{216}$ Each of the two projects involves interbank settlement in central bank money and is characterized as a proof of concept of a DLT-based wholesale payment system. Thereunder, a central bank issues a 'currency' against some of its assets. More specifically, in a DLT-based wholesale payment system, the central bank issues to each participating bank digital depository receipts against the security of funds withdrawn from the reserve account of that bank. For each payment order processed, interbank settlement continuously takes place by transacting with these digital receipts over the blockchain.

In Jasper, Digital Depository Receipts (DDRs) issued by the Bank of Canada are secured by an omnibus account in which each participating bank deposits central bank money withdrawn from its settlement account. In Ubin, Depository Receipts (DRs) are issued by the Monetary Authority to each participating bank against central bank money deposited by the latter in an

\footnotetext{
${ }^{213}$ For the distinction see UK Government Office for Science, note 160 \& text, supra.

${ }^{214}$ See: James Chapman, Rodney Garratt et al., "Project Jasper: Are Distributed Wholesale Payment Systems Feasible Yet?" (2017) Bank of Canada Financial System Review, online: <http://www.bankofcanada.ca/wpcontent/uploads/2017/05/fsr-june-2017-chapman.pdf>, accessed 28 December 2017. For the earlier stage of the project see Rod Garratt, “CAD-coin versus Fedcoin” (May 2017), online: <https://www.finextra.com/finextradownloads/newsdocs/cad-coin-versus.pdf>, accessed 28 December 2017. Also see:

Laura Shin, "Canada Has Been Experimenting With A Digital Fiat Currency Called CAD-COIN", Forbes (16 June 2016), online: <http://www.forbes.com/sites/laurashin/2016/06/16/canada-has-been-experimenting-with-a-digitalfiat-currency-called-cad-coin/\#536fabe91b0c>, accessed 28 December 2017; Pete Rizzo, "Bank of Canada Demos Blockchain-Based Digital Dollar", CoinDesk.com (16 June 2016), online: <http://www.coindesk.com/bank-canadademos-blockchain-based-digital-dollar/>, accessed 28 December 2017; and Claire Brownell, "No cryptocurrency anytime soon, Bank of Canada says: 'We're very far off'”, Financial Post (17 June 2016), online $<$ http://business.financialpost.com/news/fp-street/no-cryptocurrency-anytime-soon-bank-of-canada-says-were-veryfar-off>, accessed 28 December 2017.
}

${ }^{215}$ See: Deloitte \& MAS (Monetary Authority of Singapore), "The future is here - Project Ubin: SGD on Distributed Ledger" (2017), online:

$<$ http://www.mas.gov.sg/ /media/ProjectUbin/Project\%20Ubin\%20\%20SGD\%20on\%20Distributed\%20Ledger.pdf $>$, accessed 28 December 2017.

${ }^{216}$ For hybrid cryptocurrencies see note 158 \& text, supra. For the inherent paradox in hybrid RSBC schemes see e.g. Kartik Hegadekatti, "The K-Y Paradox: Problems in Creating a Centralised Sovereign Backed Cryptocurrency on a Decentralised Platform” (2017), MPRA Paper No 82863, online: <https://mpra.ub.uni-muenchen.de/82863/>, accessed 12 March 2018. 
individual cash custody account held with the former. ${ }^{217}$ In Ubin participating banks may hold deposit receipt balances on the blockchain overnight and have greater flexibility in pledging and redeeming DRs during operating hours. In Jasper DDRs are created and destroyed upon redemption on a daily basis.

Ubin uses a system built on the Ethereum platform. This was true for the first phase of Jasper (Jasper 1). This platform uses Proof of Work (PoW) consensus protocol, requiring expensive computations to validate transactions and update the ledger. ${ }^{218}$ For that reason the second phase of Jasper (Jasper II) switched to the Corda platform in which a notary function replaces that of the PoW:

A key feature of Corda is that updates to the ledger are achieved through two functions: a validation function and a uniqueness function. The validation function, performed by the parties involved in the transaction, ensures that all details of the transaction are correct and that the sender has the required funds. The uniqueness function is performed by a notary. ${ }^{219}$

The notary role in Jasper II is assigned to the Bank of Canada. As such it has access to the entire ledger and is able to verify that the funds involved in a transaction are available.

Since the validation of each transaction in Corda is exclusively a matter for its parties this platform is advantageous also from the confidentiality perspective. However, this feature is achieved at a cost, in the form of having a single point of failure, a drawback which is reinforced in Jasper II by assigning the notary role to one institution, i.e. the Bank of Canada. ${ }^{220}$

217 The Bank of Canada and the Monetary Authority of Singapore are respectively the central banks of Canada and Singapore.

${ }^{218}$ Briefly stated, "[p]roof of work is a requirement that expensive computations, also called mining ... be performed in order to facilitate transactions on the blockchain." In the process of generating the proof or work, 'miners' compete to

find a number that, when added to [a new] block of transactions, causes this block to hash to a code with certain rare properties. Based on the cryptographic features of the hash function used in this process, finding such a rare number is hard, but verifying its validity when it is found is easy.

Aleksandr Bulkin, "Explaining blockchain — how proof of work enables trustless consensus" (May 2016), online: $<$ https://keepingstock.net/explaining-blockchain-how-proof-of-work-enables-trustless-consensus-2abed27f0845>, accessed 28 December 2017.

${ }^{219}$ James Chapman, Rodney Garratt et al., supra note 214 at 5.

${ }^{220}$ A point acknowledged (without reference to Jasper) by S. Scorer, "Central Bank Digital Currency: DLT, or Not DLT?", Bank Underground (5 June 2017), online: <https://bankunderground.co.uk/2017/06/05/central-bank-digitalcurrency-dlt-or-not-dlt-that-is-the-question/>, accessed 28 December 2017. 
Jasper II improved on both Jasper 1 and Ubin in facilitating a liquidity-saving mechanism (LSM) in the form of a payment queue with periodic multilateral payment netting for payments designated as 'non-urgent'.

In the final analysis both Jasper and Ubin have been successful as a proof of concept for a DLT-based interbank settlement system that has the potential of replacing the traditional Realtime Gross Settlement (RTGS). However, in assessing Jasper, it was concluded that: ${ }^{221}$

- For critical financial market infrastructures, such as wholesale payment systems, current versions of DLT may not provide an overall net benefit relative to current centralized systems. Recent versions of DLT have, however, made advances compared with initial cryptocurrency applications of DLT.

- Benefits for the financial system of a DLT-based wholesale payment system could likely arise from its interaction with a larger DLT ecosystem of financial market infrastructures, potentially including cross-border transactions

It is interesting to speculate whether inter-customer settlement could be worked on a blockchain. The logistical difficulties appear to be more formidable than those existing to an interbank settlement as in Jasper and Ubin. This is so if only because of the larger number of participants and the less predictable volume, value, and frequency of payments. But even if logistics are resolved the fundamental deficiencies of the blockchain settlement remain a hindrance.

Indeed, the promise of the blockchain is in bypassing intermediaries. However, this occurs at a cost, ${ }^{222}$ e.g. the need for PoW or a notary, the latter being a central bank, commercial bank, or anybody else. This is on the top of legal and technological uncertainties to be overcome. At the same time, a distinctive feature is that of transparency that may not present in a centralized system. Furthermore, it is said that DLT developments have been occurring at an accelerated pace; ${ }^{223}$ DLT functionality does not stand still and DLT flaws are constantly addressed. Arguably, DLT potential has not been exhausted, so that whether in the future enhanced technology will provide the required benefits so as to encourage a move towards a

\footnotetext{
${ }^{221}$ James Chapman, Rodney Garratt et al., supra note 214 at 1.

${ }^{222}$ For some discussion see e.g. Markus Demary \& Vera Demary, "Financial Technology: The Promise of Blockchain" (2017) IW-Kurzberichte from Institut der deutschen Wirtschaft Köln (IW) / Cologne Institute for Economic Research No 1. 2017, online: <https://www.econstor.eu/bitstream/10419/157588/1/IWKurzbericht_2017-01.pdf>, accessed 28 December 2017.
}

${ }^{223}$ See e.g. Alexander Lipton, Blockchains and Distributed Ledgers in Retrospective and Perspective, 7 March 2017, online: <https://arxiv.org/pdf/1703.01505.pdf>, accessed 28 December 2017. 
DLT-based settlement system is a matter of speculation. However, in an environment of ongoing improvements in legacy systems DLT faces an uphill battle which it may not win. ${ }^{224}$

Thus, at the moment, each country keeps upgrading its own legacy system. The fast payment model ${ }^{225}$ is a case to the point. Progress has also been made in global funds transfers. Thus, with the advent of enhanced technologies, thought has been given to the synchronization of a multi-leg funds transfer. This is to be carried out by earmarking liquidity for each leg in advance so as to facilitate an uninterrupted continuous execution of all payment orders, e.g. from an originating bank to its foreign correspondent and onward to the beneficiary's bank. ${ }^{226}$

For its part, SWIFT launched overlay services that leverage its global payments innovation ('gpi) platform to facilitate seamless fast payments of which operation is premised on tightening up procedures, and yet with minimal changes to processing, that is, with a thin technology overlay. For now, this platform is available for the serial and not cover method for the transfer of funds. ${ }^{227}$ Principal features can be outlined as follows: ${ }^{228}$

1. All the banks in the chain agree (and are required by the rulebook) to complete processing "quickly" (hours) so that end to end is done within a day.

2. At every step of the way agents (banks) send the update to the SWIFT tracker so that it is always possible to know where the transaction is.

\footnotetext{
${ }^{224}$ For a negative assessment see e.g. Kai Stinchcombe, "Ten years in, nobody has come up with a use for blockchain", Hackernoon (22 December 2017), online: <https://hackernoon.com/ten-years-in-nobody-has-come-upwith-a-use-case-for-blockchain-ee98c180100>, accessed 9 January 2018.

${ }^{225}$ See note $107 \&$ text, supra.

226 “A new RTGS service for the United Kingdom: safeguarding stability, enabling innovation" (September 2016) Bank of England at 27-30, online: <http://www.bankofengland.co.uk/markets/Documents/paymentsystem/cp160916.pdf>, accessed 28 December 2017. The two specific scenarios addressed in connection with this option involve foreign exchange (discussed further below in this Section) and securities purchase transactions.
}

${ }^{227}$ Briefly stated the serial method involves a funds transfer carried out by a series of payments for each payment order from each sending bank to a receiving bank. Conversely, the cover method decouples the settlement from the payment information. Thus, between two end banks to a funds transfer that are neither correspondents nor participant in a clearing system, the originating bank sends a direct message to the beneficiary's bank, whereas the settlement instruction (the cover payment) is sent via intermediary banks through the path of direct correspondent banking relationships. In practice the beneficiary's bank will pay to the beneficiary prior to the arrival of cover either at its risk or in reliance of a credit line it extends either to the originating or paying bank. See in general: CPMI, supra note 87 at 34-35.

${ }^{228}$ See in general e.g: <http://opengovasia.com/articles/7731-swift-launches-industry-challenge-to-develop-overlayservices-that-leverage-its-global-payments-innovation-platform>, accessed 28 December 2017. See also:

$<$ https://www.swift.com/our-solutions/global-financial-messaging/payments-cash-management/swift-gpi>, accessed 28 December 2017; and < https://www.swift.com/resource/swift-gpi-brochure>, accessed 28 December 2017. 
3. Even when dipping out of SWIFT (e.g. SWIFT $\rightarrow$ Fed $\rightarrow$ SWIFT), the Universally Unique Identifier (UUID) is preserved and the bank that sends to the Fed and the bank that receives from the Fed notify the tracker, so that information is complete.

In order to enhance cross-border payments, SWIFT has created a new service level agreement (SLA) rulebook facilitating enhanced business practices and smart collaboration between participating banks. To monitor adherence to this new SLA for all members, SWIFT has created a central service called the Observer. All gpi banks will have a global view of other gpi banks' adherence to the SLA. This will enable gpi banks to quickly pinpoint potential areas for improvement and work collaboratively towards a better implementation of the SLA.

This is a three-stage project. The first phase of SWIFT gpi enables faster, same day use of funds (within the time zone of the receiving gpi member) and unaltered transfer of remittance information, which provides transparency of fees and end-to-end payments tracking. The second phase is designed to allow banks to transmit rich payment data as well as to immediately stop a payment, no matter where it is in the correspondence and to further increase the straight-throughprocessing rate of cross-border payments, at origination.

Indeed, against the background of these tangible achievements, SWIFT gpi is plunging towards the unknown. Thus, for its third phase, SWIFT gpi has already started exploring the potential of using new technologies such as DLT albeit solely in order to reconcile banks' nostro accounts held in foreign currency with a correspondent bank in real-time (and not for the settlement of payments). Regardless of whether this stage will be successful, it is unclear how it will be an improvement by reference to the two earlier stages as well as how it will fit the otherwise centralized nature of a legacy system.

The ultimate success of SWIFT gpi or any similar system depends on expanding its functionality by being transformed from a purely interbank system into a comprehensive system integrating within it internal bank systems. So far this may have been accomplished by Ripple blockchain ${ }^{229}$ - albeit among a small exclusive group of elite global banks, something that appears to be however within the reach of SWIFT gpi as well. The real challenge for SWIFT gpi is to encompass in such an integrative global system all members, something which Ripple blockchain is not necessarily better positioned to do.

DLT technologies could still be considered in connection with banking operations for multi-leg international remittances ${ }^{230}$ as well as interledger international transfers. ${ }^{231}$ The latter have the potential of reconciling the accounts of customers of two banks even before the completion of the interbank settlement. However, in light of the above-mentioned SWIFT gpi

\footnotetext{
${ }^{229}$ See text and notes 202 and 203, supra.

${ }^{230}$ In such a scenario outgoing payment in a conventional currency (of the payer) will be converted to Bitcoin at the point of transmission and back to a conventional currency (of the payee) at the point of receipt. Due to the short duration of the transmission Bitcoin value fluctuation may not be significant.

${ }^{231}$ Mills, supra note 161 at 19.
} 
developments, and as long as DLT transactions move slowly and are not efficient - the advantage may be neither significant nor everlasting.

\section{(iv)_Claim-check centralized digital currencies}

In expressing a clear preference to an account-based CBDC over tokens CBDC Bordo and Levin presupposed that the use of tokens requires blockchain settlement and that tokens cannot earn interest. They also asserted that the cost for verification for a token-based system would be inherently expensive. ${ }^{232}$ However, interest can be added to tokens when they are redeemed. ${ }^{233}$ Furthermore, as will be seen below, neither costly transfer, nor cumbersome procedure, nor blockchain settlement are essential ingredients of a claim-check tokenized system.

Thus, payments by means of claim-check centralized digital currencies, whether virtual or CBDC, made directly between wallets accessed from one digital or mobile device to another and not through accounts, raise another set of challenges for banks. This can be demonstrated by the operation of a couple of available technologies. Both are centralized and have high scalability. Each of them bypasses physical delivery of cash to ATMs as well as to bank branches and of course in payment for goods and services. Their method of distribution to the public will however mimic the current system of physical delivery. Thus, banks will hold inventories of digital coins; they will get them by buying them from the issuer, e.g. by having their accounts with the issuer, the central bank in the case of CBDC, debited. Similarly, bank customers will 'buy' them from their respective banks usually by having their respective accounts debited. Customers could thus withdraw and deposit digital cash to their bank accounts exactly as they do so with banknotes; of course, upon such deposits, customers replace ownership in digital coins for a claim against their bank for funds on deposit. While holding digital coins, customers will have them on their wallets and could pay from wallet to wallet without going through bank accounts. Of course, customers may also deliver their digital coins for true safe keeping with institutions that will provide such services.

The first available technology to be addressed is that of WingCash. It is a centralized system under which a claim-check to fiat currency may be issued. ${ }^{234}$ It is a multi-issuer platform that allows the issuer to determine the reserve requirement. Claims to fiat currencies issued by commercial banks may be issued against a balance in a bank account at 1:1 ratio. 'Brand value' issued by businesses can be closed-loop and is usually not backed by value in a commercial account.

Each claim-check is in the form of a unique web page with an immutably assigned web

\footnotetext{
${ }^{232}$ Bordo and Levin, supra note 132 at 6-7.

${ }^{233}$ Samid, supra note 146 at 29.

${ }^{234}$ For some information visit <www.wingcash.com>, accessed 28 December 2017 as well as <www.wingcash.org>, accessed 28 December 2017.
} 
address (URL), typically cryptographically signed by the issuer. It is described as a digital bearer instrument which simulates a physical banknote. Once denominated, the value of the note does not change. Consequently, a $\$ 1$ note can be exchanged for four $\$ .25$ notes. As well, each digital bearer instrument has a single 'possession' attribute so that only the current holder can reassign 'possession' to another entity. The ledger immediately records the update to the 'possession' attribute to avoid the double-spending problem. As in the case of physical cash, the change of possession from one holder to another constitutes a payment. Therefore, the ledger keeps a record of the change of 'possession' of each bearer instrument. Digital notes may be redeemed to fiat currency in the form of either physical cash or bank money.

Each web-page has certainly unique and separate identity so as to be dealt with as a digital coin. The architectural design of the WingCash platform uses a centralized model, allowing for the ledger to replicate in multiple locations. This offers both redundancy and scalability. One purpose of this feature is to allow for failover. If there is a failure in one location, traffic will automatically be routed to another location. It also helps to facilitate access and speed.

The United States Federal Reserve established in 2015 a 331-member Faster Payments Task Force to support a broader effort to improve the speed, safety, and efficiency of payments. ${ }^{235}$ On March 29, 2016 McKinsey \& Company was selected to support Faster Payments Task Force efforts to assess faster payments solution proposals from various providers across the United States payments industry. ${ }^{236}$ Among the 17 faster payments solutions, WingCash came tied in the first place. ${ }^{237}$ Its proposal is described as:

A software platform that would be owned and operated by the Federal Reserve and the Governing Organization. ${ }^{238}$ The Federal Reserve would issue digital currency (digital Fed notes) and is tied to the Internet domain (Fednotes.com).

This faster payment solution proposal "seek[s] to make it possible for any entity to transfer value electronically using methods that seek to preserve and to emulate physical currency."

Accordingly, its Faster Payments Network (FPN) will allow "persons and businesses to hold and transfer digital Fed notes for payment, with the direction of payment flow from the Payer directly to the Payee." Thus, ${ }^{239}$

\footnotetext{
235 "Strategies for Improving U.S. Payment System" (26 January 2015) Federal Reserve System, online: $<$ https://fedpaymentsimprovement.org/wp-content/uploads/strategies-improving-us-payment-system.pdf $>$, accessed 28 December 2017.

236 "Federal Reserve engages in effort to access faster payments solutions" (29 March 2016) Federal Reserve, online: <https://www.federalreserve.gov/newsevents/press/other/20160329a.html>, accessed 28 December 2017.

${ }^{237}$ See "The U.S. Path to Faster Payments FINAL REPORT PART TWO: A CALL FOR ACTION" (July 2017) Faster Payments Task Force at 13, online: <https://fasterpaymentstaskforce.org/wp-content/uploads/fasterpayments-task-force-final-report-part-two.pdf>, accessed 28 December 2017.

${ }^{238}$ Defined in the Glossary as "The executive officers, board of directors and board of advisors responsible for governing the Raster Payments Network [- FPN]"
} 
... the FPN specifies a single Internet domain ... where the Federal Reserve publishes digital bills and coins (Fed notes). Each Fed note is a unique web page with an immutably assigned URL that includes both a currency code (e.g., USD) and a unique identifier similar to a serial number... Combined these components form a unique immutable address for each Fed note ...

The Fed notes would constitute 'legal tender' so as to be the equivalent of US physical currency. "[E]ach Fed note is assigned a single, permanent, monetary unit of value "... as well as "a field that stores the URL of the issuer ... and a field that stores the URL of the current holder...." Each Fed note would be cryptographically 'signed' by the 'Fed' using 'asymmetric (public key) cryptography' (PKC), with the Fed also acting as the Certificate Authority (CA). Fed notes are to be transferred by means of an exchange of cryptographically 'signed' messages from the payer to the Fed, (with a copy to the payee) followed by a message from the Fed to the payee. With the completion of each payment, the FPN updates the possession of attribute of the Fed note from the payer to the payee. In the process, the Fed thus acts not only as the issuer but also as a controller of the Internet domain associated with each Fed note and custodian of the transfer record.

The WingCash proposed solution envisages the use by the Fed of the WingCash platform. It is a platform that allow a safe and secure transfer of value among individuals and businesses. The Network has two distinct parts: one allowing Treasury to design and issue digital Fed notes. The second is to be operated by the Fed (either directly or through a Governing Organization), and consist of a global directory service distributing the digital notes and records their transfer. Initial distribution is to be made by the Fed to banks which will make the digital notes available for withdrawals to their customers. Both successful competition and interoperability with existing networks such as $\mathrm{ACH}$ and cards is anticipated. ${ }^{240}$

If Bitcoin is the epitome of a decentralized, self-anchored, speculative, and unstable cryptocurrency, then BitMint, the second technology to be addressed, stands on the other end of the digital currencies spectrum, facilitating, among other features, a centralized scheme for a non-speculative and stable currency, consisting of randomized coins, each expressing a claimcheck to a defined quantity of a specific commodity, including a fiat currency. ${ }^{241}$ BitMint keeps $100 \%$ reserve so that the purchasing commodity or fiat currency is always available for redemption on demand. Its functionality not only overlaps with that of Bitcoin but also exceeds

\footnotetext{
${ }^{239}$ WingCash (Proposer), "Faster Payments QIAT" (21 February 2017) at 11 and 14, online: <https://drive.google.com/file/d/OB_CNPQWTRQwuZWhqbDUzNVJsNGc/view>, accessed 28 December 2017.

${ }^{240}$ For extensive information, see documents accessed (through 'WingCash') supra note 239 at 13: $<$ http://fasterpaymentsnetwork.com/>, accessed 28 December 2017; <https://drive.google.com/file/d/0B_CNPQWTRQwuc1hhWlAzOEljNGs/view>, accessed 28 December 2017; and <https://drive.google.com/file/d/0B_CNPQWTRQwuZWhqbDUzNVJsNGc/view>, accessed 28 December 2017.

${ }^{241}$ For detailed information on BitMint (not to be confused with BintMinter), see e.g.: < http://www.bitmint.com/>, accessed 12 March 2017; <http://finder.startupnationcentral.org/company_page/bitmint/>, accessed 12 March 2017 , and sites and videos accessible through it; and <https://medium.com/@bitmintnews>, accessed 12 March 2017, and associated articles.
} 
it. BitMint is thus said to be identified as "the only candidate qualifying as a universal digital representation of worldwide currencies." 242

BitMint is leading a grand vision for the future of money as both a specific money protocol and a generic money framework. The value of its currency is non-speculative. It is protected by quantum physics, not dependent on erosive encryption, and claimed to be indefeasible by cyber threats. Facilitating private issuance of the currency, BitMint envisions its redemption at a central mint by the fiat currency or commodity by which it is fully backed. It is also suitable as a digitized central bank currency. ${ }^{243}$ While it is a centralized system, BitMint includes a Validation Hierarchy under which BitMint coins are validated through subordinate nodes.

BitMint may be tethered. ${ }^{244}$ 'Tethered money' is defined to mean " $[\mathrm{m}]$ oney with built-in limitation on its use."245 Paper-based travelers' checks, available for use only by their purchasers, ${ }^{246}$ are an example to paper-based tethered currency. ${ }^{247}$ Coupons available for use in limited locations or at designated businesses are another example of tethered paper currency. Scriptural central bank money may also be tethered by setting limitations and restrictions to its use. Tethering, however, is hard to achieve for bank money, since it requires ongoing involvement of the payer in the distribution of funds by the payee. In any event, tethering is unavailable for central bank physical currency. At the same time, tethering is in principle extensively available for digital currency.

Tethering is an important tool for budgeting, gifting and grant giving, as it releases the payer from the heavy burden of monitoring and overseeing the actual use of the money in compliance with the terms under which it was paid. It thus eliminates both waste and corruption. A few examples may be helpful. A lender providing a car loan can tether the money so that the borrower can use it only in payment to any or a specific car dealer. A donor may tether the donation so that the recipient will be able to use the money only for the purpose of the donation. An individual paying a spouse for the support of their children can tether the money so that it will be usable only for that purpose. Treasury may allocate funds and provide them tethered for the purpose allocated under the budget or grant. ${ }^{248}$

\footnotetext{
${ }^{242}$ See this quote from Helmut Scherzer, Senior Principal Technology Manager for Giesecke \& Devrient at the Chip-to-Cloud Security Forum, held September 25-17, 2013, Nice, French Riviera. It is online at slide no. 16 in <http://pennwell.sds06.websds.net/2015/amsterdam/slideshows/T1S7O3-slides.pdf>, accessed 28 December 2017.

${ }^{243}$ For details, see Gideon Samid, "Bitcoin.BitMint: Reconciling Bitcoin with Central Banks", BitMint, LLC, online: <https://eprint.iacr.org/2014/244.pdf>, accessed 28 December 2017. See also e.g.

$<$ http://www.bitmint.com/bitcoin.htm>, accessed 28 December 2017.

${ }^{244}$ Samid, supra note 146 at 108.

${ }^{245}$ Samid, ibid. at 140 (Glossary).

${ }^{246}$ For a classic analysis, see Eliahu P Ellinger, “Travellers' Cheques and the Law” (1969) 19 UTLJ 132.

${ }^{247}$ See e.g. Samid, supra note 146 at xxi (on paper travelers' checks) and 50 (effects of tethering).
} 
Tethering may designate a redeemer of the digital coin, e.g. an officer of a given corporation or a resident in a small city. The latter case may be through a local or community money scheme under which tax or other benefits are given to support economic activity in the locality or community. Alternatively, money given as a construction loan may be limited for redemption only by qualified contractors to ensure that the borrower is not spending the money to go on vacation. In the further alternative, tethered money may be redeemable from date certain to date certain. A renter could use such coins to pay his or her rent a year ahead and specify, for each coin, the next month as the window of redemption for that coin. Similarly, money can be tethered to be payable only upon (or, alternatively, before) the occurrence of a specified event.

As an option, a digital coin may be set for redemption only if it carries with it its entire history. In fact, the sky is the limit: money can be tethered with anything, that is, with any restriction or limitation to its use that can algorithmically be checked and verified with no ambiguity is a bona fide term of payment.

To that end, tethering is available as a means of protection for digital money on hand. Thus, even where 'storage' is successfully hacked, digital coins cryptographically linked to the rightful owner will not be redeemable by the thief or anyone deriving title from the thief. ${ }^{249}$ Indeed, when paid with digital coins and for their own protection, payees are well advised to consult the 'oracle' for the validity of the coins, including their availability to be payable to them, free of any tethering-driven limitation. At least to the extent that digital currency is 'money', which ought not to be an issue for digital currency lawfully issued by a central bank, misappropriated and untethered digital coins will pass to an innocent taker for value free of any adverse claim. ${ }^{250}$ As well, cryptographic storage is akin to bailment and, unlike the bank deposit, not a loan ${ }^{251}$ so as not to charge the custodian with absolute liability for loss caused by hacking. ${ }^{252}$ At the same time, to enhance protection, digital coins cryptographically stored at a bank could be 'double-tethered', both to the bank and the owner.

BitMint may also be cascaded. Cascaded digital money is denominated in a unit of account anchored on the value of two or more fiat currencies, commodities, or indices, and used as agreed either bilaterally or multilaterally, particularly in macro and cross-border payments. It is envisioned to be a "dynamic competitive market carried out through a web of mints (the intermint) that will adhere to a binding protocol to allow for a smooth interchange on a global scale." ${ }^{253}$ Each level of mints will create a currency that is a claim-check to a specific mix or

\footnotetext{
${ }^{248}$ Samid, ibid at 27 (basis of tethering), 33-68 (use and impact of tethering).

${ }^{249}$ Samid, ibid at 50 and 100.

250 The classic case for this proposition is Miller v Race (1758), 1 Burr 452; 97 ER 398.

${ }^{251}$ The classic case supporting the proposition that the bank deposit is a loan is Foley $v$ Hill (1848), 2 HLC 28, 9 E.R. 1002 .

${ }^{252}$ A classic case linking custodian responsibility to a duty of care is Coggs v Bernard (1703), 2 Ld Raym 909, 92 E.R. 107.

${ }^{253}$ Samid, supra 146 at 65.
} 
cocktail of commodities and/or fiat currencies as 'represented' in the 'combined' currencies of lower level mints. As the cascade climbs up, it is expected to create "joint currencies that would increasingly represent the wealth of humanity in total". ${ }^{254}$ It is predicted that this "will not kill fiat currencies, as they would serve as the bases for the cascaded currency, and the better managed each fiat currency, the higher would [raise] its share in the cascaded global currency." 255

Available tethering facilitates crypto-fusing contractual terms between payer to payee into the money, so as to disallow any use that is in breach of the contract. Available tethering further includes the option of making BitMint money accessible only to an identifiable holder. Obviously, this greatly enhances security and safety and reduces fraud. As well, the protocol may accommodate either a design under which the issue, every transfer and the redemption are recorded or a design where only the issue and redemption are recorded. Under the latter design, transfers between issue and redemption are not registered and remain anonymous. As discussed, the latter option nevertheless accommodates inquiries with the 'oracle' and does not preclude tethering. Furthermore, bypassing a centralized protocol operator does not inhibit law enforcement and combatting money laundering or anti-terrorism finance. For BitMint, being a centralized system, this is due to the issuer's ability to list a suspect as non-compliant.

BitMint money is generated through an economical quantum mechanical process ${ }^{256}$ which is energy-efficient and reduces waste. Being not dependent on erosive cryptography, and instead expressed in a string consisting of sequences of bits that are totally and completely random and pattern-less, its coins are immune against brute force cracking as well as against hacking and quantum computing. In addition, BitMint money can be split off or amalgamated at any desired resolution, so that each digital coin is readily amenable to either split into smaller coins or amalgamate (with one or more coins) into a larger one, with each such a new coin being represented by a substring of the original coin(s). ${ }^{257}$ BitMint bit-string money can be paid continuously on a pay-as-you-go basis, e.g. as you pump gas into a car gas tank, rather than separately, e.g. upon the completion of the service. Available technologies also facilitate safe storage and speedy transfer by electronic means. Its currency/payment protocol enables direct payments between digital devices of payer and payee, and further facilitates both macro and micro payments in open and close loops, as well as in loyalty schemes.

In the final analysis, in the absence of intermediaries a payee receiving payment by means of a claim-check centralized digital currency may easily verify both the validity of the coin and the identity of the sender. Moreover, in the absence of receiving account information, a dishonest payee will find it difficult to misuse such information. Hence, assuming a continuous

\footnotetext{
${ }^{254}$ Samid, ibid at 65.

${ }^{255}$ Samid, ibid at 22.

${ }^{256}$ On this process, see e.g. $<$ https://en.wikipedia.org/wiki/Introduction_to_quantum_mechanics $>$, accessed 28 December 2017.

${ }^{257}$ For details on randomized or entropic coins, see Samid, supra note 146 at 106-108.
} 
process of technological enhancement, there are reasonable grounds to assume successful penetration of such currencies and the methods of payment with them.

It is hard to predict to what extent payments in centralized digital currencies will superseded those intermediated through banks. Possibly, both practicalities and anti-money laundering \& terrorist financing regulations may limit the size of payments made in claim-check centralized digital currencies, the latter being in some way analogous to cash payments, so as to make them more labour-intensive for payments of large sums. Furthermore, the chance is that for a large payment, an RTGS system, with liquidity-saving mechanisms, settled between commercial banks on the books of a trusted central bank, will be preferred by participants over a large peer to peer digital cash payment between them. ${ }^{258}$

In any event, commercial banks may undertake several roles in an environment in which claim-check centralized digital currencies are widely spread. First, they could provide storage facilities for customers. In such a case their liability to customers will be as guardians or bailees; such liability depends on fault and is not absolute as that of a debtor on a bank deposit. On the top of this, commercial banks could offer competing terms for holding funds in accounts held by them in conjunction with offering payment services for claim-check centralized digital currencies that could be withdrawn from such accounts. Banks will be able to provide overdraft facilities in connection with accounts something which storage facilities for digital currencies will not be able to do. Second, commercial banks may act as issuers of virtual, particularly cascaded, digital currencies. Third, banks will remain capable of lending into accounts they maintain for customers and in any event may set the terms under which digital currencies will be withdrawn from such accounts particularly if they are directed to use for payment from a platform not controlled by the bank maintaining the account. The chance is that broad investment powers in relation to money on deposit, whether under a fractional or full reserve system, will allow banks to continue to benefit from combining deposit taking and the provision of payment services.

\section{$\underline{\text { IV. Conclusion }}$}

Born in Antiquity and reborn in the Middle Ages, each time as an extension of money changing, banking became a business combining deposit taking and lending. On and off banks have been linked to money creation but have always operated non-cash payment services.

Banking services emerged in Ancient Mesopotamia. The first banks appeared in Greece; they moved to Rome and were set up in Greco-Roman Egypt where the first bank network as well as the first national payment system, even if only in kind and not money, is recorded. Banks reappeared in West Europe in the late Middle Ages to take deposits, lend and provide payment services. However, in Medieval Europe, it was the merchant banker, and not the deposit taker, that gave rise to multilateral clearing and the clearing house. It was post-medieval England that in a gradual process, lasting into the early modern period, has produced the modern national banking network headed by the central bank. When the dust had settled, the scene crystalized to

\footnotetext{
${ }^{258}$ See e.g. Walter Engert and Ben S C Fung, "Central Bank Digital Currency: Motivations and Implications", Bank of Canada, Staff Discussion Paper 2017-16 at 16-17, online: <https://www.bankofcanada.ca/wpcontent/uploads/2017/11/sdp2017-16.pdf>, accessed 9 January 2018.
} 
consist of (i) a network of clearing commercial banks taking deposits, lending while creating money in the process, and providing payment services, side by side with (ii) a central bank issuing money in the form of banknotes and the maintenance of settlement accounts for banks, providing with lender of last resort facilities, as well as managing the quantity of money to ensure price stability throughout the national economy.

Money and payment digitization has brought some challenges to the traditional role of banks as intermediaries. First, the digital age is about to facilitate the availability of central bank money balances or their equivalent to the public. Second, cryptocurrencies and blockchains were born. Third, claim-check centralized digital currencies have been created. This paper argues that availability of central bank money, in the form of either full-reserve banking or plain sovereign money, is unlikely to affect the role of banks other than in money creation. They will remain deposit takers, lenders and providers of payment services. The paper goes on to argue that cryptocurrencies are mostly not a new form of money and that in essence blockchains do not pose a major threat to the traditional interbank settlement system; at most they spur improvements in legacy systems. Finally, the argument goes, the creation of claim-check centralized digital currencies will give banks enough space to continue their role in providing payment services and even create alternative currencies fully backed by fiat ones. In short, in the long run, to stay competitive, no model other than banking is available to IT firms entering the payment industry. Banking has not been mortally wounded by Fintech; rather, as the banking network has become ready to absorb IT firms transformed to banks, banking is alive and well. 


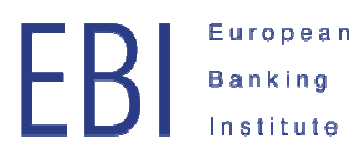

$\underline{\text { Address }}$

European Banking Institute eV.

Mainzer Landstrasse 251

60326 Frankfurt am Main

Germany

For further information please visit our website www,ebi-europa.eu or contact us at info@ebi-europa.eu 
The European academic joint venture for research in banking regulation

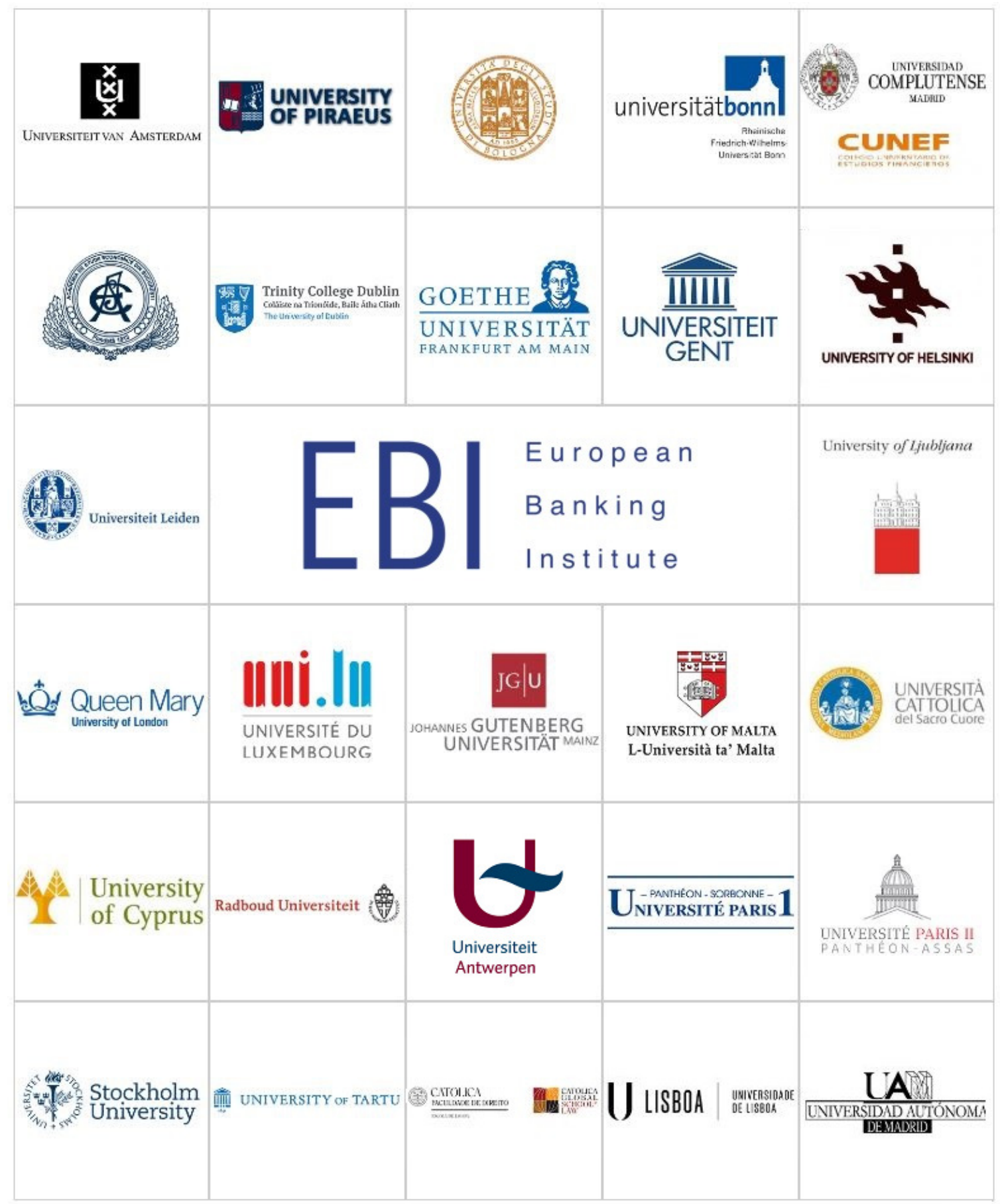

